\title{
What is the importance of climate model bias when projecting the impacts of climate change on land surface processes?
}

\author{
M. Liu ${ }^{1}$, K. Rajagopalan ${ }^{1}$, S. H. Chung ${ }^{1}$, X. Jiang ${ }^{2}$, J. Harrison ${ }^{3}$, T. Nergui ${ }^{1}$, A. Guenther ${ }^{1,4}$, C. Miller ${ }^{3}$, J. Reyes ${ }^{1}$, \\ C. Tague ${ }^{5}$, J. Choate ${ }^{5}$, E. P. Salathé ${ }^{6}$, C. O. Stöckle ${ }^{7}$, and J. C. Adam ${ }^{1}$ \\ ${ }^{1}$ Civil and Environ Engineering, Washington State University, Pullman, WA, USA \\ ${ }^{2}$ Atmospheric Chemistry Division, NCAR Earth System Laboratory, Boulder, CO, USA \\ ${ }^{3}$ School of the Environment, Washington State University, Vancouver, WA, USA \\ ${ }^{4}$ Atmospheric Sciences and Global Change, Pacific Northwest National Laboratory, Richland WA, USA \\ ${ }^{5}$ Bren School of Environmental Science \& Management, University of California, Santa Barbara, CA, USA \\ ${ }^{6}$ School of Science Technology Engineering and Mathematics, University of Washington, Bothell, WA, USA \\ ${ }^{7}$ Department of Biological Systems Engineering, Washington State University, Pullman, WA, USA
}

Correspondence to: J. C. Adam (jcadam@wsu.edu)

Received: 22 August 2013 - Published in Biogeosciences Discuss.: 4 November 2013

Revised: 14 March 2014 - Accepted: 28 March 2014 - Published: 16 May 2014

\begin{abstract}
Regional climate change impact (CCI) studies have widely involved downscaling and bias correcting (BC) global climate model (GCM)-projected climate for driving land surface models. However, BC may cause uncertainties in projecting hydrologic and biogeochemical responses to future climate due to the impaired spatiotemporal covariance of climate variables and a breakdown of physical conservation principles. Here we quantify the impact of BC on simulated climate-driven changes in water variables (evapotranspiration (ET), runoff, snow water equivalent (SWE), and water demand for irrigation), crop yield, biogenic volatile organic compounds (BVOC), nitric oxide (NO) emissions, and dissolved inorganic nitrogen (DIN) export over the $\mathrm{Pa}$ cific Northwest (PNW) region. We also quantify the impacts on net primary production (NPP) over a small watershed in the region (HJ-Andrews). Simulation results from the coupled ECHAM5-MPI-OM model with A1B emission scenario were first dynamically downscaled to $12 \mathrm{~km}$ resolution with the WRF model. Then a quantile-mapping-based statistical downscaling model was used to downscale them into $1 / 16^{\circ}$ resolution daily climate data over historical and future periods. Two climate data series were generated, with bias correction (BC) and without bias correction (NBC). Impact models were then applied to estimate hydrologic and biogeochemical responses to both $\mathrm{BC}$ and NBC meteorological data sets. These impact models include a macroscale hydro-
\end{abstract}

logic model (VIC), a coupled cropping system model (VICCropSyst), an ecohydrological model (RHESSys), a biogenic emissions model (MEGAN), and a nutrient export model (Global-NEWS).

Results demonstrate that the $\mathrm{BC}$ and $\mathrm{NBC}$ climate data provide consistent estimates of the climate-driven changes in water fluxes (ET, runoff, and water demand), VOCs (isoprene and monoterpenes) and NO emissions, mean crop yield, and river DIN export over the PNW domain. However, significant differences rise from projected SWE, crop yield from dry lands, and HJ-Andrews's ET between BC and NBC data. Even though $\mathrm{BC}$ post-processing has no significant impacts on most of the studied variables when taking PNW as a whole, their effects have large spatial variations and some local areas are substantially influenced. In addition, there are months during which $\mathrm{BC}$ and NBC post-processing produces significant differences in projected changes, such as summer runoff. Factor-controlled simulations indicate that BC post-processing of precipitation and temperature both substantially contribute to these differences at regional scales.

We conclude that there are trade-offs between using BC climate data for offline CCI studies versus directly modeled climate data. These trade-offs should be considered when designing integrated modeling frameworks for specific applications; for example, $\mathrm{BC}$ may be more important when considering impacts on reservoir operations in mountain- 
ous watersheds than when investigating impacts on biogenic emissions and air quality, for which VOCs are a primary indicator.

\section{Introduction}

"To bias-correct or not?" is debated in the scientific community (Ehret et al., 2012; Hagemann et al., 2011; Muerth et al., 2013). Bias correction (BC) discussed here is the process of adjusting global climate model (GCM) or regional climate model (RCM) output - mainly temperature $(T)$ and precipitation $(P)$ - depending on discrepancies between observed and modeled results over the period of observation. While BC is a post-processing step that is a widely applied for climate change impact (CCI) studies, there are several known issues. One concern is that most studies that use BC GCM/RCM data without adequate quantification of the effects of BC, thereby introducing additional uncertainties (Ehret et al., 2012; Muerth et al., 2013; Teutschbein and Seibert, 2012).

Bias in climate models can be attributed to uncertainties in representations of atmospheric physics (Maraun, 2012), boundary conditions and initialization (Bromwich et al., 2013), inadequate reference data sets such as reanalysis data (Dee et al., 2011a, 2011b; Thorne and Vose, 2010), climate variability (Ehret et al., 2012), limitations in input data resolution (Wood et al., 2011), and simplifications required due to limited computing capacity. BC of GCM/RCM output as a post-processing step has been used to address this deficiency (Wood et al., 2004). While GCMs/RCMs should continue to be developed to improve predictability, current deficiencies in GCMs/RCMs often necessitate correction of resulting climate biases to make the data useful as input for CCI studies.

Ehret (2012) reviewed the problems in using BC GCM/RCM data, including problematic assumptions of stationarity of the error statistics, independently adjusting climate variables, and lack of a physical basis. Several recent studies have questioned the validity of common assumptions for the BC process (Berg et al., 2009; Christensen et al., 2008; Haerter et al., 2011; Hagemann et al., 2011; Johnson and Sharma, 2012; Maraun, 2012; Piani et al., 2010; Vannitsem, 2011). Recent advancement in BC methodology addresses some of these shortcomings. For example, there are methods that allow for correction of biases in $T$ and $P$ while preserving the relationships between them (Hoffmann and Rath, 2012; Piani and Haerter, 2012) and attempts to allow non-stationary BC (Buser et al., 2009). Vannitsem et al. (2011) question the utility of BC particularly in the context of decadal forecasts of a transient climate, which is a timescale of importance in many impact studies; for example, many state planning agencies operate on a 20 -year horizon, irrigation infrastructure and farm machinery often have 10- year investment payback periods, and perennial crops have investment horizons of 10 to 30 years.

Although the deficiencies of $\mathrm{BC}$ are known, the effects of $\mathrm{BC}$ on the climate change signal and hence the consequences of $\mathrm{BC}$ on hydrometeorology, biogeochemistry, ecological, and agricultural estimates are still unclear. Recently, studies have attempted to quantify the effects of bias correcting input climate data on model outcomes (Chen et al., 2011; Hagemann et al., 2011; Muerth et al., 2013). Results indicate that although $\mathrm{BC}$ better reproduces historical observations, it can also alter the climate change signal for certain locations (Hagemann et al., 2011), and/or for certain indicators (Muerth et al., 2013). However, these studies are currently limited to stand-alone hydrologic models. There is a need to characterize how BC of modeled climate data affects the projection of land surface response and impacts to water quality/quantity, ecosystem productivity, and emissions of reactive species that influence air quality.

As Earth system models (EaSMs) currently stand, there are trade-offs associated with the decision to use offline (with BC) or online (without BC) simulations. While BC enhances model skill with respect to observations, it often violates laws for conservation of mass and energy that are fundamental to non-BC models. Although NBC climate predictions are often inconsistent with observations in terms of absolute magnitudes, CCI studies based on these data sets or online models often carry the assumption that these models may still be useful to characterize changes between current and future conditions. The central questions this paper addresses are as follows: to what extent do CCI impacts (represented by the difference between future and historical hydrologic/biogeochemical simulations) differ when driving land surface models by simulated meteorology with and without $\mathrm{BC}$, and what are the implications of these differences? In short, to what extent does BC matter in terms of projecting the response of the land surface?

The objective of this work is to understand and quantify the sensitivity of multiple decision-relevant variables (related to hydrology, agriculture, ecosystems, air quality, and nutrient export) to the $\mathrm{BC}$ post-process on climate data. To achieve this objective, we use both BC and NBC meteorological variables as input to drive impact models that cover regional and watershed-scale hydrology, crop growth and phenology, river nutrient export, and biogenic emissions. This allows EaSM teams to make better-informed decisions on the tradeoffs that exist when developing an integrated modeling application for a specific natural or agricultural management question. 


\section{Methods}

\subsection{Study domain description}

The domain of this study is the US Pacific Northwest region (PNW), which includes the Columbia River basin (CRB) and coastal watersheds in the states of Washington and Oregon (Fig. 1). The region supports a vast array of agricultural and natural resources. However, due to its winterdominated precipitation and associated large seasonal storage of water as snowpack, this region faces substantial risk from global warming (Adam et al., 2014; Liu et al., 2013; Mote, 2003). Farmland occupies $11 \%$ of the CRB, with a highly diverse mix of crops, including alfalfa, hay, winter wheat, apples, sweet corn, potatoes, and sugar beets (National Research Council, 2004). Across the PNW region, $31 \%$ of all farmland is irrigated, and $70 \%$ of this land area is irrigated from surface water (USDA National Agricultural Statistics Service, 2008).

For investigating impacts on forest ecosystems, we perform a watershed-scale simulation on the National Science Foundation (NSF) Long-Term Ecological Research (LTER) HJ-Andrews site in central Oregon (see inset in Fig. 1). Located along the western slopes of the Cascade Mountain Range, the site encompasses $64 \mathrm{~km}^{2}$ and extends to the Lookout Creek watershed boundaries, which drains to the McKenzie River.

\subsection{Land surface model descriptions}

Impact models being used for this study are major components from a regional Earth system model (BioEarth) currently in development that aims to improve understanding of interactions among carbon, nitrogen, and water at the regional scale, in the context of global change, to inform decision makers' strategies regarding natural and agricultural resource management (Adam et al., 2014). These models include a macroscale hydrologic model (VIC), a coupled cropping system model (VIC-CropSyst), an ecohydrologic model (RHESSys), a biogenic emissions model (MEGAN), and a nutrient export model (Global-NEWS). Each of these models is described briefly below.

The Variable Infiltration Capacity (VIC; Liang et al., 1994) model is a fully distributed, physically based, macroscale model that solves the water and energy budgets for every grid cell in the study domain. It was developed for largescale applications $\left(1 / 16^{\circ}-2^{\circ}\right)$, and subgrid heterogeneities in land cover and topography are considered. VIC account for key moisture and energy fluxes between the land surface and the atmosphere, and includes algorithms for shallow subsurface (frozen and unfrozen) moisture, snow, lake, and wetland dynamics (Andreadis et al., 2009; Bowling and Lettenmaier, 2010; Cherkauer and Lettenmaier, 2003). VIC has been applied over all continental land areas, and has been used extensively over the PNW (Adam et al., 2009; Elsner et al., 2010;

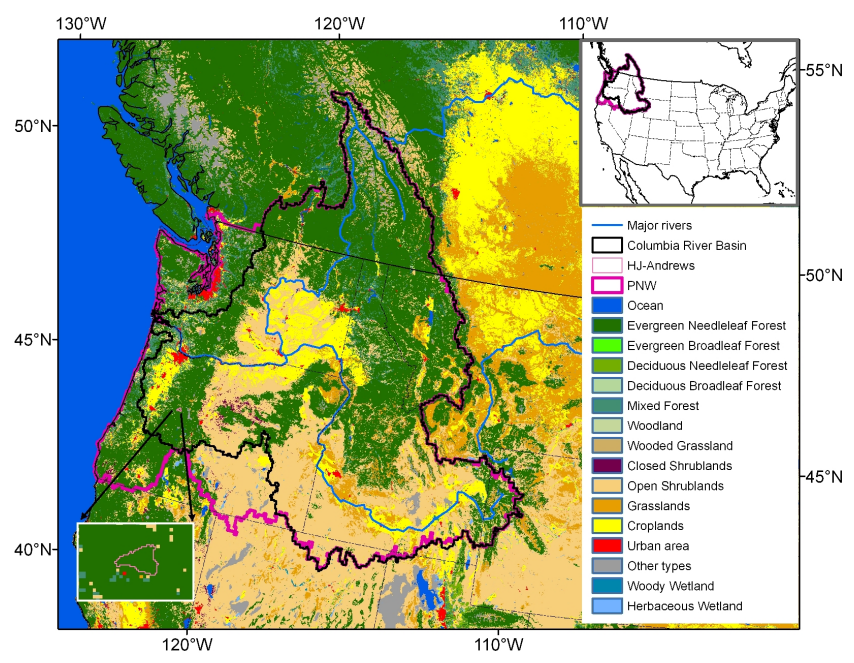

Fig. 1. Study area and simulation domain for this study. Pacific Northwest: VIC, VIC-CropSyst, and MEGAN domains; Columbia River basin: NEWS-DIN domain; HJ-Andrews: RHESSys domain.

Hamlet et al., 2007, 2012; Hamlet and Lettenmaier, 2005; Liu et al., 2013; Maurer et al., 2002). In this application, we use the implementation (version 4.0.7) described by Hamlet et al. (2012).

CropSyst (Stöckle et al., 1994, 2003) is a field-scale, multi-year, multi-crop model developed to serve as an analytical tool to study the effect of climate, soils, and management on cropping systems productivity, nutrient cycling and fate, and the environment. Management options include crop rotation, cultivar selection, irrigation, nitrogen fertilization, tillage operations, and residue management. CropSyst has been evaluated and used in the PNW (e.g., Peralta and Stöckle, 2002) and around the world (e.g., Stöckle et al., 2003). A simplified version of CropSyst that focuses on water use and productivity was extracted for coupling with the VIC hydrology model (VIC-CropSyst v1.1; Rajagopalan et al., in preparation). VIC passes meteorological and hydrological parameters to CropSyst and CropSyst handles crop growth and passes irrigation demand to VIC. The crop distribution and irrigation extension was generated from cropland data of the Washington State Department of Agriculture and the Cropland Data Layer from the United States of Department of Agriculture (USDA) (USDA National Agricultural Statistics Service Cropland Data Layer, 2011). Irrigation extent outside Washington state is identified from survey data. All irrigated croplands are assumed to be managed with ideal irrigation practices, i.e., without drought-induced interruptions to water rights (Yorgey et al., 2011).

The Regional Hydro-Ecologic Simulation System (RHESSys v5.15; Tague and Band, 2004) is a physically based watershed-scale ecohydrological model designed to simulate climate and land use change impacts on ecosystem carbon and nutrient cycling and hydrology. It uses an 
adaptation of BIOME-BGC (White and Running, 1994) and a modified version of the Century-NGAS model (Parton et al., 1993) to simulate above- and belowground carbon and nitrogen processes. RHESSys fully couples these biogeochemical processes with a spatially distributed hydrologic model. RHESSys has been applied in a number of different environments, including watersheds in the PNW (e.g., Christensen et al., 2008; Meentemeyer and Moody, 2002; Tague and Grant, 2009; Tague et al., 2007, 2008a, b, 2009, 2013; Zierl and Bugmann, 2005).

The Model of Emissions of Gases and Aerosols from Nature (MEGAN v2.1; Guenther et al., 2012) incorporates recent advances in the understanding of the processes controlling biogenic emissions (e.g., solar radiation, temperature, soil moisture, carbon dioxide concentration, vegetation type, leaf age, and LAI) at a resolution suitable for regional modeling. While MEGANv2.1 can be run as an offline model or as an integrated component of land surface and atmospheric chemistry models, we used the offline version for this study. As we are most interested in examining the climate change impacts on biogenic emissions, the land cover used in all simulations was kept constant (i.e., year 2008 conditions) based on MODIS LAI and plant functional types (PFTs) (Guenther et al., 2012; http://acd.ucar.edu/ guenther/MEGAN/MEGAN.htm).

The Global Nutrient Export from Water(S)heds (Global NEWS v2.0) model predicts annual average export of multiple forms of carbon and multiple nutrients as a function of climate, basin characteristics, and human activities within watersheds. NEWS sub-models have been applied broadly to understand land-to-ocean transport of carbon and nutrients at regional and global scales (Dumont et al., 2005; Harrison et al., 2005a, b, 2010; Mayorga et al., 2010; Seitzinger et al., 2005, 2010). More recently, NEWS sub-models have been successfully applied at regional and sub-basin spatial scales and at monthly timescales (Harrison et al., 2010; McCrackin et al., 2013; Thieu et al., 2010) as well as in hindcast and scenario modes to examine historic and potential future changes in coastal nutrient loading (Seitzinger et al., 2010). For this study, we apply the NEWS-DIN model to simulate the dissolved inorganic nitrogen (DIN) export from the CRB as a result of human activities, natural processes, and in-stream removal processes (Dumont et al., 2005; Mayorga et al., 2010; Seitzinger et al., 2002). Nutrient loading and reservoir information used by NEWS is derived from prior global-scale analyses (Bouwman et al., 2010; Van Drecht et al., 2009).

\subsection{Climate data}

The climate data for this study are output from a regional climate model simulation using the Weather Research and Forecasting (WRF; Skamarock et al., 2008) model to dynamically downscale a coupled global general circulation model consisting of ECHAM5 (the atmospheric component) (Roeckner et al., 1999, 2003) and the Max Planck Institute Ocean
Model (MPI-OM; Marsland et al., 2003) (the ocean component). These simulations are described in detail by Salathé et al. (2013) and briefly summarized here. For the historical period (1970-1999), the ECHAM5-MPI-OM simulations of the 20th century forced by historical greenhouse gas concentration, aerosol, and solar forcing were used; for the 21st century, simulated results with the A1B emissions scenario of the Special Report on Emissions Scenarios (SRES) were used. The A1B is a medium-high greenhouse gas emission scenario that is for "business as usual" in the first half of the 21 st century with greater mitigation in the second half, and a balanced energy system (Nakicenovic and Swart, 2000).

The implementation of the WRF model used in this study for the PNW is described and evaluated in Zhang et al. (2009) and Duliere et al. (2011). The simulations used nested grids at 36 and $12 \mathrm{~km}$ spacing. The $12 \mathrm{~km}$ nest covers the region shown in Fig. 1. The outer $36 \mathrm{~km}$ nest receives boundary conditions and interior nudging from the global ECHAM5-MPIOM fields; the inner $12 \mathrm{~km}$ nest is forced only at its boundary by the outer nest (i.e., without nudging). Gridded analysis nudging was applied only to the outer nest, only on upper air wind, temperature, and moisture fields, and only on wind in the planetary boundary layer. The simulations use the following parameterization choices in WRF: WRF Single-Moment 5-class (WSM5) microphysics (Hong et al., 2004), KainFritsch convection (Kain and Fritsch, 1993), the NOAH landsurface model (Chen and Dudhia, 2001), the YSU (Hong and Pan, 1996) boundary layer, and NCAR CAM shortwave and longwave radiation (Collins et al., 2004).

Although regional-scale climate models represent the important mesoscale weather and climate features far better than global models, the simulations are still subject to biases resulting from deficiencies in both the global forcing fields and the regional model (Christensen et al., 2008; Wood et al., 2004). To obtain acceptable hydrologic simulations, these biases must be removed. In addition, to link the WRF results to the VIC hydrologic model, the simulations require additional downscaling from the $12 \mathrm{~km}$ WRF grid to the $1 / 16^{\circ}$ $\left(0.0625^{\circ}\right)$ VIC grid. These downscaling and BC steps are performed as follows: first the WRF simulations of temperature $(T)$, precipitation $(P)$, and wind speed at $12 \mathrm{~km} \times 12 \mathrm{~km}$ grid cells and 6-hour time step were aggregated to daily average $T$ and wind speed and daily total $P$. The daily maximum and minimum $T$ were identified from these four sub-daily records. These data were then downscaled to $1 / 16^{\circ}$ with the Symap algorithm, which uses a four-nearest-neighbor inverse-distance weighting approach (Maurer et al., 2002; Shepard, 1984). Re-gridded $T$ and $P$ were then subjected to $\mathrm{BC}$ by using a quantile-mapping approach applied at daily time step, and detailed descriptions can be found in Salathé et al. (2013) and Wood et al. (2002); this method is termed bias correction-statistical downscaling (BCSD). The quantile-mapping $\mathrm{BC}$ is achieved by replacing simulated values for $T$ and $P$ with values having the same percentiles (non-exceedance probabilities) (Wood et al., 2002). For each 
grid cell, cumulative distribution functions (CDF) of $T$ and $P$ were generated for each calendar month and climate scenario for both observation and projections. For a given period of GCM-WRF projections, the quantile-mapping algorithm looks up the simulated CDF during the training period (1970-1999). The corresponding quantile value from the observed CDF then replaces the simulated value for that period. For future periods, systematic shifts in the magnitude and variance result in projected $T$ and $P$ falling outside of the original CDF of the training period. Thus, for each 30-year future period, the average shift in $T$ is removed before $\mathrm{BC}$ but is added back after the corresponding value is identified in the simulated $\mathrm{CDF}$ of the draining period. However, extrapolation of the CDF during the training period is still needed because future simulated $T$ or $P$ frequently fall outside its range. For this study, values that fall outside the simulated training-period $\mathrm{CDF}$ were mapped to an equivalent observed value via the multiplicative $(P)$ or additive $(T)$ anomaly from the observed mean.

Re-gridded wind speed from WRF was applied directly without BC. The observed training data for the quantile mapping were from gridded historical $T$ and $P$ (Elsner et al., 2010, Hamlet et al., 2012; also used in this study as baseline runs for the 1980s) and applied to WRF-simulated variables for both historical and future periods (Table 1). The wind speed data in the observed historical climate were re-gridded from reanalysis data (Elsner et al., 2010). The assumption for this quantile-based $\mathrm{BC}$ approach is that historical biases in WRF simulations are comparable to those that would occur over future climates (Salathe et al., 2013). BCSD downscaling largely preserved the spatial details of precipitation and temperature from the regional climate model, while removing systematic biases (determined by comparison with observations) without losing the simulated spatial correlation between $T$ and $P$ (Salathe et al., 2013; Wood et al., 2002). Themessl et al. (2011) provided a detailed review on seven major statistical-downscaling and BC approaches and concluded that quantile mapping has advantages in removing regional climate model deficiencies in the entire $P$ distribution (including mean, day-to-day variability, and extremes). Recently, by using BCSD approach, a new archive of downscaled Coupled Model Intercomparison Project Phase 5 (CMIP5) (Taylor et al., 2012) climate projections for the conterminous United States, called NASA Earth Exchange (NEX) Downscaled Climate Projections at 30 arcseconds (NEX-DCP30), has been generated from NEX platform and distributed through the NASA Center for Climate Simulation (NCCS) (Thrasher et al., 2013). NEX-DCP30 contains more than 100 downscaled climate projections from 33 CMIP5 GCMs and 4 RCP scenarios (Thrasher et al., 2013). This case study on the hydrologic and biogeochemical consequences from the BCSD quantile-mapping approach can provide valuable information to communities using this data set and the typical statistical-downscaling method.
Table 1. List of climate scenarios for this study. All WRF simulations used as boundary conditions results from the coupled ECHAM5-MPI-OM model run with the IPCC SRES A1B scenario (Salathé et al., 2010, 2013).

\begin{tabular}{llll}
\hline $\begin{array}{l}\text { Time } \\
\text { period }\end{array}$ & Source & $\begin{array}{l}\text { Bias-corrected } \\
\text { variable }\end{array}$ & $\begin{array}{l}\text { Variable } \\
\text { name }\end{array}$ \\
\hline $1970-1999$ & $\begin{array}{l}\text { Gridded } \\
\text { observed }\end{array}$ & - & OBS \\
& WRF & $T \& P$ & $\mathrm{BC}_{T \& P, 1980 \mathrm{~s}}$ \\
& WRF & $T$ & $\mathrm{BC}_{T, 1980 \mathrm{~s}}$ \\
& WRF & $P$ & $\mathrm{BC}_{P, 1980 \mathrm{~s}}$ \\
& WRF & None & $\mathrm{NBC}_{T \& P, 1980 \mathrm{~s}}$ \\
& & & \\
$2010-2039$ & WRF & $T \& P$ & $\mathrm{BC}_{T \& P, 2020 \mathrm{~s}}$ \\
& WRF & $T$ & $\mathrm{BC}_{T, 2020 \mathrm{~s}}$ \\
& WRF & $P$ & $\mathrm{BC}_{P, 2020 \mathrm{~s}}$ \\
& WRF & None & $\mathrm{NBC}_{T \& P, 2020 \mathrm{~s}}$ \\
& & & $\mathrm{BC}_{T \& P, 2050 \mathrm{~s}}$ \\
& WRF & $T \& P$ & $\mathrm{BC}_{T, 2050 \mathrm{~s}}$ \\
& WRF & $T$ & $\mathrm{BC}_{P, 2050 \mathrm{~s}}$ \\
& WRF & $P$ & $\mathrm{NBC}_{T \& P, 2050 \mathrm{~s}}$ \\
\hline
\end{tabular}

The VIC model uses daily $T$ (including daily maximum and minimum $T$ ) and $P$ to simulate other meteorological variables including short- and longwave radiation, surface temperature, and relative humidity by solving surface energy budget equations and using algorithms from the Mountain Microclimate Simulation Model (MTCLIM; Bohn et al., 2013; Hungerford et al., 1989; Kimball et al., 1997; Thornton and Running, 1999; Thornton et al., 2000) (Liang et al., 1994; Maurer et al., 2002). RHESSys uses a similar approach to estimate other meteorological variables relying on $T$ and $P$ (Tague and Band, 2004). The meteorological driving forces for MEGAN were from VIC-modeled variables including surface temperature, short- and longwave radiation, and humidity (Fig. 2).

\subsection{Simulation experiments}

To quantify the effects of BC (individually on $T$ and $P$, as well as the combined effects) on projected land surface response, different combinations of BC and NBC climate data are used to drive these models (Table 1). Figure 2 demonstrates the information and work flow between each model and data source. For the RHESSys simulations, we estimate forest net primary productivity (NPP) in response to climate variation, without accounting for disturbances and changes in nitrogen limitation. Global NEWS uses annual outputs of surface runoff and baseflow from VIC offline simulations as well as irrigation water demand from VIC-CropSyst.

The following terrestrial responses to climate change and $\mathrm{BC}$ are investigated: hydrological processes (evapotranspiration, ET; runoff; and snowpack water equivalent, SWE), 

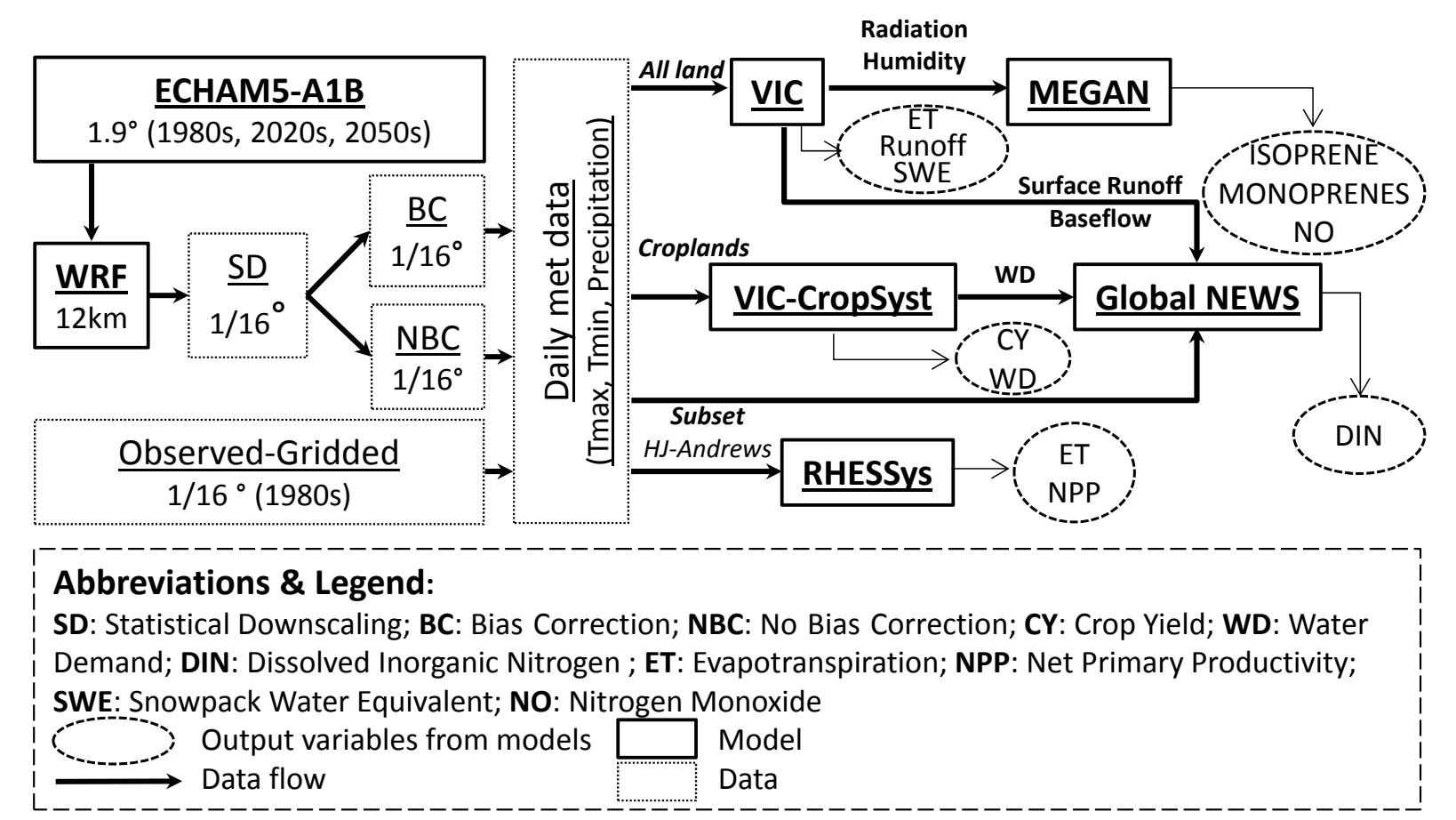

Fig. 2. Offline simulations and data flow for this study.

agricultural processes (crop yields, CY; irrigation water demand, WD), emissions of gases that contributes to ozone and aerosol formation in the atmosphere (isoprene; monoterpenes; and nitrogen monoxide, NO), river export of DIN, and forest NPP (Fig. 2). Except for MEGAN, all model simulations are performed for three 30-year periods: 19701999 (hereafter, 1980s), 2010-2039 (2020s), and 2040-2069 (2050s). For each 30-year period, only the most recent 25 years of simulated results are used in analyses, providing a 5 -year model spin-up period. MEGAN simulations are conducted with 25-year-averaged climate data for each period.

\subsection{Attributing individual and combining effects of $T$ and $P$ bias corrections}

The projected impact of climate change on a given variable is quantified as a percentage change (Eqs. 1 and 2).

$$
\begin{aligned}
& \Delta \mathrm{BC}_{T \& P, t}(\%)=\frac{\mathrm{BC}_{T \& P, t}-\mathrm{BC}_{T \& P, 1980 s}}{\mathrm{BC}_{T \& P, 1980 s}} \times 100 \% \\
& \Delta \mathrm{NBC}_{T \& P, t}(\%)= \\
& \frac{\mathrm{NBC}_{T \& P, t}-\mathrm{NBC}_{T \& P, 1980 s}}{N \mathrm{BC}_{T \& P, 1980 s}} \times 100 \%,
\end{aligned}
$$

where $t$ is time period in the future (i.e., 2020s or 2050s), $\triangle \mathrm{BC}(\%)$ is the estimated change in percentage based on $\mathrm{BC}$ climate data, while $\triangle \mathrm{NBC}(\%)$ is the percentage change from $\mathrm{NBC}$ data; $\mathrm{BC}_{T \& P, t}\left(\right.$ or $\mathrm{NBC}_{T \& P, t}$ ) represents the simulated results during period $t$ with $\mathrm{BC}$ (or NBC) data; and $T \& P$ indicates that both $T$ and $P$ are treated the same (either both
$\mathrm{BC}$ or both $\mathrm{NBC})$. The total BC-derived discrepancy in the projected impact was calculated with Eq. (3).

$\operatorname{eff}_{T \& P, t}=\Delta \mathrm{BC}_{T \& P, t}(\%)-\Delta \mathrm{NBC}_{T \& P, t}(\%)$

The rationale for calculating this discrepancy is that, while there might be significant differences in simulated variables driven by $\mathrm{BC}$ and NBC climate data, the estimated percentage change between the future and historical periods may possibly not be as dissimilar because the $\mathrm{BC}$ process is designed to conserve the changes in $T$ and $P$ between future and historical periods. In this case, $\operatorname{eff}_{T \& P, t}$ from Eq. (3) would be small enough that the BC process would not be necessary for this certain variable if its relative change is the major consideration in a particular decision-making process.

We also consider the individual roles of $\mathrm{BC}$ of $P$ and $\mathrm{BC}$ of $T$ have on percentage change. Equation (6) is used to quantify the impact due to $\mathrm{BC}$ of $T$ but not $P$, and Eq. (7) was used to quantify the impact due to $\mathrm{BC}$ of $P$ but not $T$.

$$
\begin{aligned}
& \Delta \mathrm{BC}_{T, t}(\%)=\frac{\mathrm{BC}_{T, \wedge P, t}-\mathrm{BC}_{T, \wedge P, 1980 s}}{\mathrm{BC}_{T, \wedge P, 1980 s}} \times 100 \%, \\
& \Delta \mathrm{BC}_{P, t}(\%)=\frac{\mathrm{BC}_{\wedge T, P, t}-\mathrm{BC}_{\wedge T, P, 1980 s}}{\mathrm{BC}_{\wedge T, P, 1980 s}} \times 100 \%, \\
& \operatorname{eff}_{T}^{t}=\frac{\left[\Delta \mathrm{BC}_{T \& P, t}(\%)-\Delta \mathrm{BC}_{P, t}(\%)\right]+\left[\Delta \mathrm{BC}_{T, t}(\%)-\Delta \mathrm{NBC}_{T \& P, t}(\%)\right]}{2} \\
& \operatorname{effr}_{P}^{t}=\frac{\left[\Delta \mathrm{BC}_{T \& P, t}(\%)-\Delta \mathrm{BC}_{T, t}(\%)\right]+\left[\Delta \mathrm{BC}_{P, t}(\%)-\Delta \mathrm{NBC}_{T \& P, t}(\%)\right]}{2}
\end{aligned}
$$


where $\Delta \mathrm{BC}_{T, t}(\%)$ and $\Delta \mathrm{BC}_{P, t}(\%)$ are the percentage change in a response variable caused by $\mathrm{BC}$ of $T$ only and BC of $P$ only, respectively; $\operatorname{eff}_{T}^{t}$ and $\operatorname{eff}_{P}^{t}$ are average effects of BC of $T$ and $\mathrm{BC}$ of $P$, respectively, under the context of interactions between $T \& P$; and the symbol $\wedge$ indicates that the variable was not bias-corrected.

\subsection{Statistical method for quantifying significance}

In this study, we emphasize the regional responses of land surface processes to $\mathrm{BC}$ and NBC climate data by examining the projected changes on summe total changes over the study domains as well as spatial variations within the domains by examining each grid cell. For the region-wide estimation, we consider the significance of $\mathrm{BC}$ effects on total water availability, yield, SWE, biogenic volatile organic compounds (BVOC), NO, and DIN export by summing over the study domains (i.e., the PNW, the CRB, or the HJ-Andrews) before applying the Student $t$ test on each response variable. In considering spatial correlations in meteorological variables, the Walker test has been widely used to estimate the significance of rejecting a global null hypothesis across a study domain by first testing the significance of each grid cell (Folland and Anderson, 2002; Livezey and Chen, 1983; von Storch, 1982; Wilks, 2006). However, strong local effects (i.e., the lowest $p$ value in the $t$ test) can dominate and result in an easier rejection of the global null hypothesis (Wilks, 2006). To examine spatial variations, we first quantified the differences and projected changes (future minus historical) in land surface processes as driven by $\mathrm{BC}$ and $\mathrm{NBC}$ climate over each grid cell. Next, we counted the percentage of grid cells over which the differences in projected changes are significant (based on relative change in percentage). In this study, we take $\alpha=0.05$ in the $t$ test as the index to claim the difference is significant.

In the $t$-test analysis, the two groups of simulated results (i.e., BC and NBC climate) were preprocessed by subtracting the mean of the historical period (i.e., mean of 1975-1999). As mentioned earlier, we report the percentage change for all targeted variables except $T$, for which we report the absolute change.

\section{Results}

We first discuss the changes to the climate signal (Sect. 3.1) and then discuss how this climate change signal translates into impacts on hydrologic and biogeochemical processes at both annual (Sect. 3.2) and seasonal (Sect. 3.3) timescales. Finally, we discuss the relative effects of $\mathrm{BC}$ on $T$ and $P$ to the overall change signal (Sect. 3.4).

\subsection{BC and NBC climate data over the historical and future periods}

When spatially averaged over the study domain, there is a significant difference between NBC downscaled climate

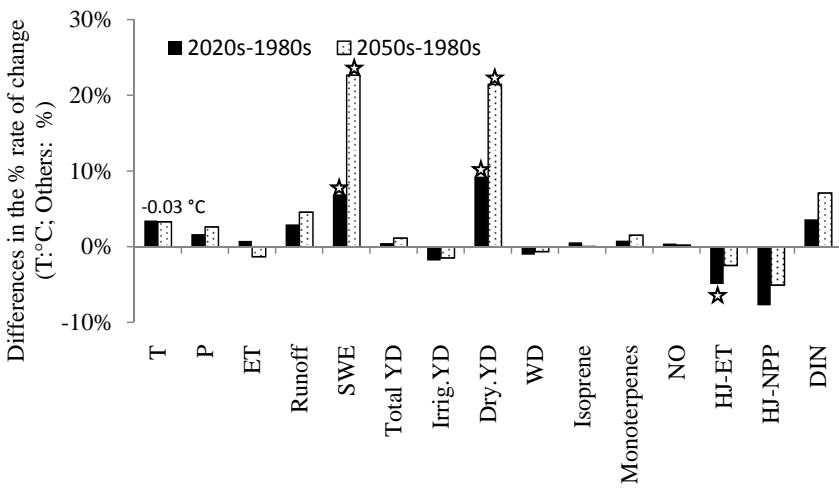

Fig. 3. Differences in the percentage change between BC and NBC climate data and the simulated outputs driven by bias-corrected (BC) and non-bias-corrected (NBC) climate. They are calculated as $\left[\Delta \mathrm{BC}_{20 \mathrm{~s}-80 \mathrm{~s}}(\%)-\Delta \mathrm{NBC}_{20 \mathrm{~s}-80 \mathrm{~s}}(\%)\right]$ for the change between the $1980 \mathrm{~s}$ and $2020 \mathrm{~s}$ and $\left[\Delta \mathrm{BC}_{50 \mathrm{~s}-80 \mathrm{~s}}(\%)-\Delta \mathrm{NBC}_{50 \mathrm{~s}-80 \mathrm{~s}}(\%)\right]$ for the change between the 1980s and 2050s. For $T$, it is total differences in degrees Celsius, i.e., $\left(\Delta \mathrm{BC}_{20 \mathrm{~s}-80 \mathrm{~s}}-\Delta \mathrm{NBC}_{20 \mathrm{~s}-80 \mathrm{~s}}\right)$ for the change between the $1980 \mathrm{~s}$ and $2020 \mathrm{~s}$, and $\left(\Delta \mathrm{BC}_{50 \mathrm{~s}-80 \mathrm{~s}}-\Delta \mathrm{NBC}_{50 \mathrm{~s}-80 \mathrm{~s}}\right)$ for the change between the 1980s and 2050s. $T$ : annual mean temperature; $P$ : average annual precipitation; ET: average annual evapotranspiration; Runoff: total runoff; SWE: snowpack water equivalent on 1 April; Total YD: total yield from all croplands; Irrig. YD: yield from irrigated cropland; Dry YD: yield from dryland (nonirrigated cropland); WD: total irrigation water demand over irrigated cropland, HJ-ET: RHESSys modeled ET over HJ-Andrews watershed; HJ-NPP: RHESSys modeled net primary production (NPP) over HJ-Andrews watershed; DIN: NEWS modeled dissolved inorganic nitrogen yield over the Columbia River basin. The small stars under or above each column represent $p$ value $<0.05$ for the Student $t$ test of differences between BC anomalies and NBC anomalies during the period of the 2020s and 2050s, respectively.

data of the 1980s (i.e., NBC climate) and observations. NBC has a mean annual $T$ and $P$ that is $2.7^{\circ} \mathrm{C}$ lower and $156 \mathrm{~mm}$ year $^{-1}$ (or $17 \%$ ) higher than observations, respectively (Table 2). After BC, the modeled climate closely matches the observations (Table 2) as expected (i.e., Salathe et al., 2013; Wood et al., 2002). The absolute projected climate change signal in $T(\Delta T)$ in the 2020s and 2050s compared to the 1980s is preserved in the BC process (Table 2). $\Delta T$ is approximately $1{ }^{\circ} \mathrm{C}$ for the period 1980s-2020s and $2.5^{\circ} \mathrm{C}$ for the period $1980 \mathrm{~s}-2050 \mathrm{~s}$ for both BC and NBC cases. The projected climate change signal of $P$ is a little higher under BC. $P$ increases by $45 \mathrm{~mm}$ year $^{-1}$ (or $5.2 \%$ ) under $\mathrm{BC}$ and $37 \mathrm{~mm} \mathrm{year}^{-1}$ (or $3.5 \%$ ) under NBC for the period 1980s-2020s, and $97 \mathrm{~mm} \mathrm{year}^{-1}$ (or $11.1 \%$ ) under BC and $89 \mathrm{mmyear}^{-1}$ (or $8.5 \%$ ) under NBC for the period 1980s-2050s. Overall, the average differences between $\mathrm{BC}$ and NBC in $\Delta T$ and percentage rate of change in $P$ $[\Delta P(\%)]$ over these two time periods (i.e., 1980s-2020s and $1980 \mathrm{~s}-2050 \mathrm{~s})$ are insignificant, i.e., $0.03^{\circ} \mathrm{C}$ (Student's $t$ test on anomaly in annual mean, $p=0.89$ ) and $2.1 \%$ (Student's $t$ test on anomaly in annual precipitation, $p=0.72$ ) (Fig. 3). 
Table 2. Changes in climate and simulated variables during the periods of 1980s-2020s and 1980s-2050s, and differences in the changes between results with bias correction (BC) and without bias correction (NBC) of climate data.

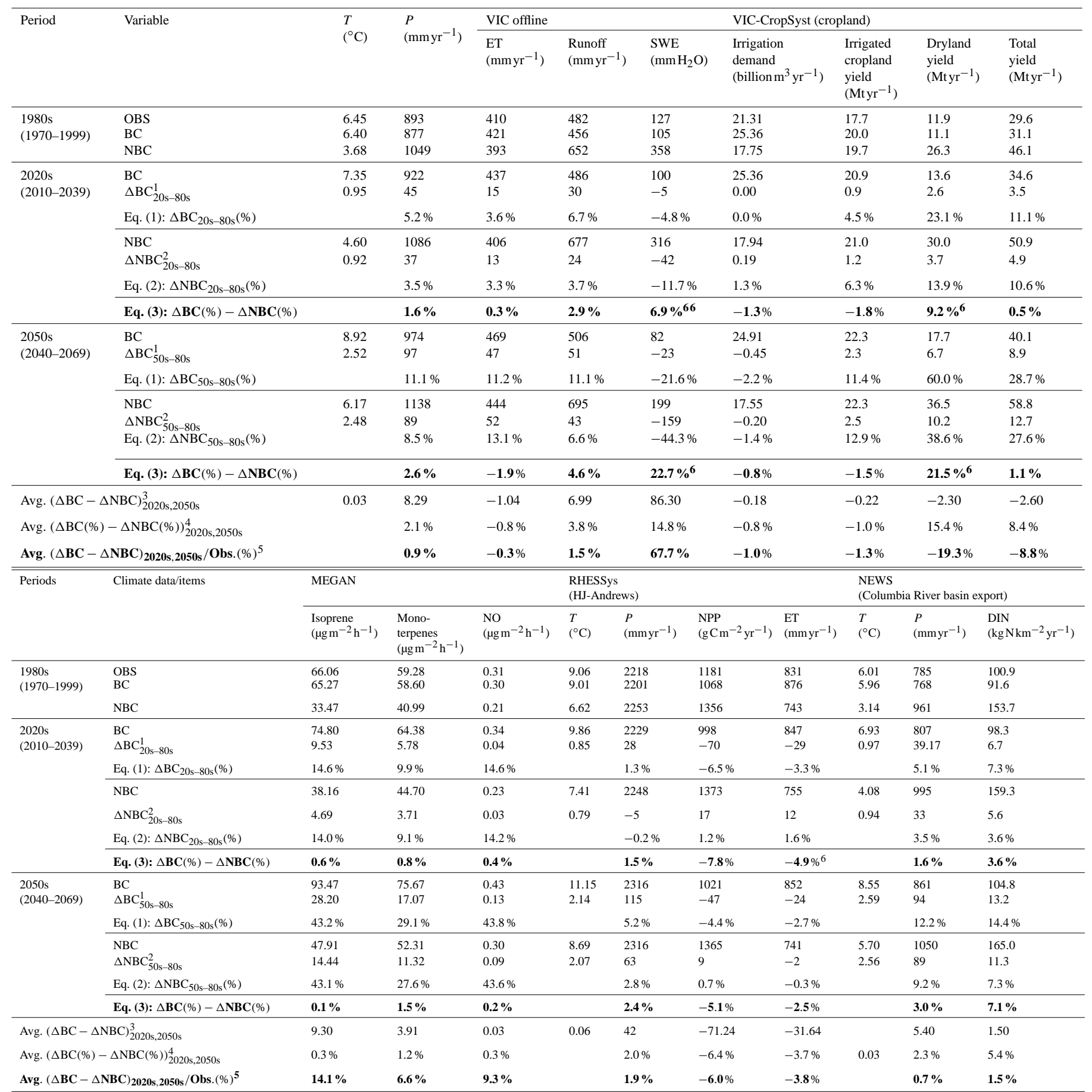

${ }_{1}^{1} \triangle \mathrm{BC}$ is the absolute change derived from BC climate between target periods; in other words, $\Delta \mathrm{BC}_{20 \mathrm{~s}-80 \mathrm{~s}}$ represents the change between the $1980 \mathrm{~s}$ and $2020 \mathrm{~s}$ and $\Delta \mathrm{BC}_{50 \mathrm{~s}-80 \mathrm{~s}}$ represents the change between the $1980 \mathrm{~s}$ and $2050 \mathrm{~s}$.

$2 \triangle \mathrm{NBC}$ is the absolute change derived from NBC climate between target periods; in other words, $\triangle \mathrm{NBC}_{20 \mathrm{~s}-80 \mathrm{~s}}$ represents the change between the $1980 \mathrm{~s}$ and $2020 \mathrm{~s}$ and $\triangle \mathrm{NBC} 50 \mathrm{~s}-80 \mathrm{~s}$ represents the change between the $1980 \mathrm{~s}$ and $2050 \mathrm{~s}$.

${ }^{3}$ The difference in absolute change between $\mathrm{BC}$ and NBC climate averaged over the changes between the $1980 \mathrm{~s}$ and $2020 \mathrm{~s}$ and between the $1980 \mathrm{~s}$ and $2050 \mathrm{~s}$, i.e., $\left[\left(\Delta \mathrm{BC}_{20 \mathrm{~s}-80 \mathrm{~s}}-\Delta \mathrm{NBC} 20 \mathrm{~s}-80 \mathrm{~s}\right)+\left(\Delta \mathrm{BC}_{50 \mathrm{~s}-80 \mathrm{~s}}-\Delta \mathrm{NBC}-\mathrm{N}_{50 \mathrm{~s}-80 \mathrm{~s}}\right)\right] / 2$.

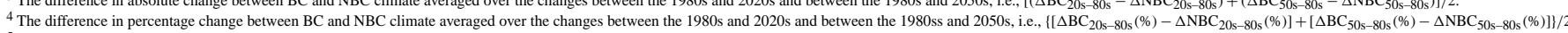

5 The percentage difference between BC and NBC climate averaged over the changes between the $1980 \mathrm{~s}$ and $2020 \mathrm{~s}$ and between the $1980 \mathrm{~s}$ and $2050 \mathrm{~s}$ and relative to observed climate (or the simulated outputs driven by observed data), i.e.,

$\left[\left(\Delta \mathrm{BC}_{20 \mathrm{~s}-80 \mathrm{~s}}-\Delta \mathrm{NBC}_{20 \mathrm{~s}-80 \mathrm{~s}}\right)+\left(\Delta \mathrm{BC}_{50 \mathrm{~s}-80 \mathrm{~s}}-\Delta \mathrm{NBC}_{50 \mathrm{~s}-80 \mathrm{~s}}\right)\right] /\left(2 \times \mathrm{Obs}_{1980 \mathrm{~s}}\right) \times 100 \%$

${ }^{6}$ This signifies a $p$ value $<0.05$ for the Student $t$ test (not applicable for MEGAN results). 


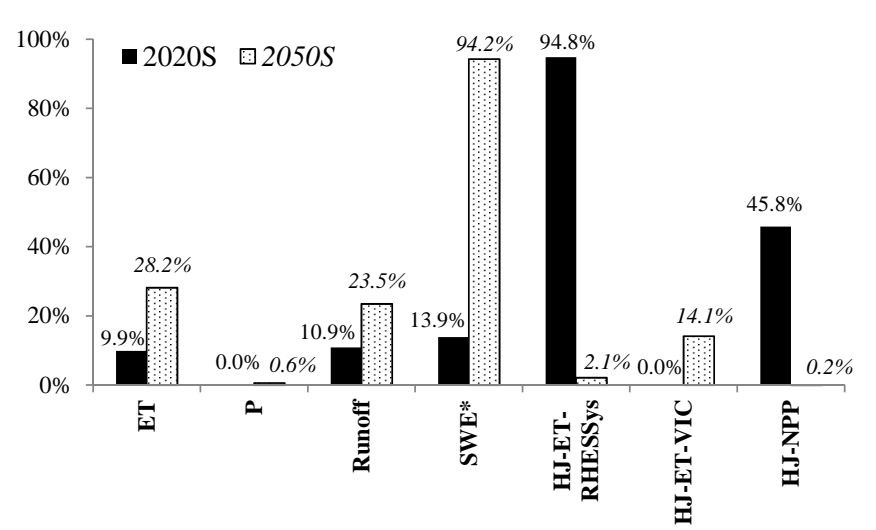

Fig. 4. Percentage of grid cells with significant differences $(p<$ 0.05 ) between the projected changes using BC and NBC climate data. Note: for 1 April SWE, the sample size is the number of grid cell that has a minimum of $25 \mathrm{~mm}$ SWE on 1 April according to observed climate for the historical period.

The downscaled ECHAM A1B simulation suggests that projected increases in $T$ and $P$ are greater in the southern PNW than in the western and central PNW in the next half century (Fig. 5a and b). Overall, BC post-processing of the downscaled climate has generally conserved the spatial patterns of $\Delta T$ and $\Delta P(\%)$ over the study domain (as compared to the original NBC climate) (Figs. 3, 4, 5a and b). However, in certain regions, such as the central floodplain between the Cascade and Rocky Mountains, the BC climate change signal $\Delta P(\%)$ is $5-10 \%$ higher than the NBC climate signal over the period of 1980s-2050s (Fig. 5b).

\subsection{Impacts of $\mathrm{BC}$ on annual-scale hydrological and biogeochemical processes}

\subsubsection{Impacts on large-scale hydrology (VIC simula- tions)}

\section{Evapotranspiration (ET)}

ET, including soil evaporation, canopy evaporation, and plant transpiration, is the total water vapor leaving the land surface to the atmosphere and is controlled by the availability of energy and water. Climate change affects ET by altering both energy and moisture availability. VIC simulations indicate that both BC and NBC climate data result in 3 and $12 \%$ increases in ET during the periods 1980s-2020s and 1980s2050s, respectively (Table 2). There are no significant differences in overall ET projections ( $p=0.52$ and 0.83 over ET anomalies in the 2020s and 2050s, respectively) (Fig. 3). However, there is a large spatial variation in the ET climate change signal between $\mathrm{BC}$ and NBC climate inputs, especially in the 2050s. Across the PNW, $28.2 \%$ of the grid cells shows significant differences in estimated ET percentage change between $\mathrm{BC}$ and $\mathrm{NBC}$ data over the period of 1980s-2050s (Fig. 4). Figure 5c shows that the use of BC climate results in reduced $\triangle \mathrm{ET}(\%)$ in high mountainous regions such as the northern Cascade Ranges and the Rocky Mountains, and higher $\triangle \mathrm{ET}(\%)$ in flat-terrain areas such as the floodplain of the Snake River and the Harney Basin, as compared to NBC climate inputs. This difference indicates that over higher mountainous terrain, similar relative warming from cooler climates (NBC data) may produce a higher ET loss than from hotter climates (BC data). While over lower altitude regions, the magnitude of ET is mostly controlled by moisture availability; that is, a higher relative $P$ increase can produce a higher relative ET increase (Fig. $5 \mathrm{~b}$ and c).

\section{Runoff}

Runoff, including baseflow and surface runoff, is the total water that flows to rivers and reservoirs. Most of the runoff in the PNW is generated from the mountainous regions (Fig. 5d). Both BC- and NBC-driven simulations predict increased runoff in the future. Use of $\mathrm{BC}$ climate data leads to projected increases of 6.7 and $11.1 \%$ in the periods of 1980s-2020s and 1980s-2050s, respectively, while use of NBC climate leads to lower increases (of 3.7 and $6.6 \%$, respectively) (Table 2, Figs. 3 and 4). Spatial patterns and overall changes in total runoff over the PNW demonstrates that changes in runoff are mostly controlled by the relative change of $P$; that is, a higher $\Delta P$ (BC data) can generate higher $\triangle$ Runoff (BC data), particularly in the context of a drier climate (BC data) (Table 2). The largest increase (up to $20 \%$ ) in runoff occurs near the confluence of the Yakima, Snake, and Columbia rivers in Washington, the Harney Basin in Oregon, the Salmon River Mountains in Idaho, and the mountainous areas in the northern PNW (Fig. 5d). Overall, $11 \%$ of the grid cells of the PNW show significant effects of BC treatment for the 2020s and this increases to $23.5 \%$ for the 2050s (Fig. 4).

\section{Snowpack water equivalent (SWE)}

April 1st SWE is a commonly used indicator of water resources availability in the western US because melting of the snowpack generates spring-summer peak flows (Adam et al., 2009; Barnett et al., 2005; Hamlet et al., 2005). Model estimates show that the mountainous areas of the northern Cascade and Rocky Mountains have larger SWE storage than any other region in the PNW (Fig. 5e). With a projected warming trend in the future, SWE will continuously decrease between the 1980s and 2050s. The BC climate change signal of 1 April SWE is significantly weaker than the NBC signal. Use of BC climate results in SWE decreases of 4.8 and $21.6 \%$ for the periods $1980 \mathrm{~s}-2020$ s and $1980 \mathrm{~s}-2050 \mathrm{~s}$, respectively, which are much lower than the change signal projected by NBC climate (11.7 and $44.3 \%$, respectively) (Table 2, Figs. 3 and 4). The differences between BC- and NBC-derived $\triangle \mathrm{SWE}(\%)$ are significant in both time periods 
a) Annual Mean Temperature $\left({ }^{\circ} \mathrm{C}\right)$
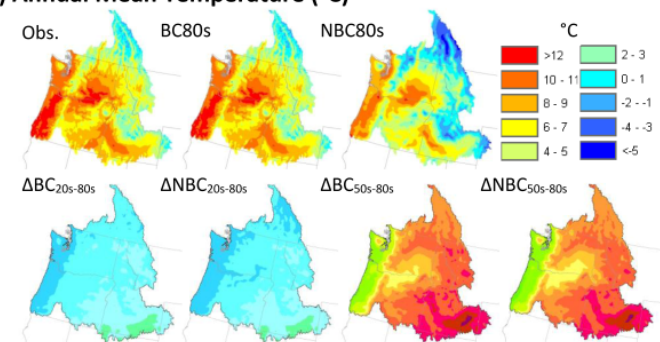

$\begin{array}{ccccccccccc}0 & 0.4 & 0.8 & 1.2 & 1.6 & 2.0 & 2.4 & 2.8 & 3.2 & 3.6 & 4.0 \\ -0.1 & -0.08 & -0.06 & -0.04 & -0.02 & 0 & 0.02 & 0.04 & 0.06 & 0.08 & 0.1\end{array}{ }^{\circ} \mathrm{C}$

$\triangle \mathrm{BC}_{20 \mathrm{~s}-80 \mathrm{~s}}-\triangle \mathrm{NBC}_{20 \mathrm{~s}-80 \mathrm{~s}} \quad \Delta \mathrm{BC}_{50 \mathrm{~s}-80 \mathrm{~s}}-\triangle \mathrm{NBC}_{50 \mathrm{~s}-80 \mathrm{~s}}$
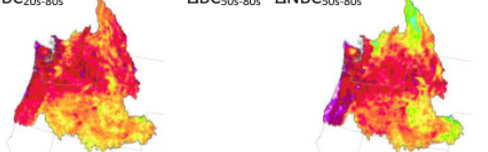

c) Annual ET (mm/year)
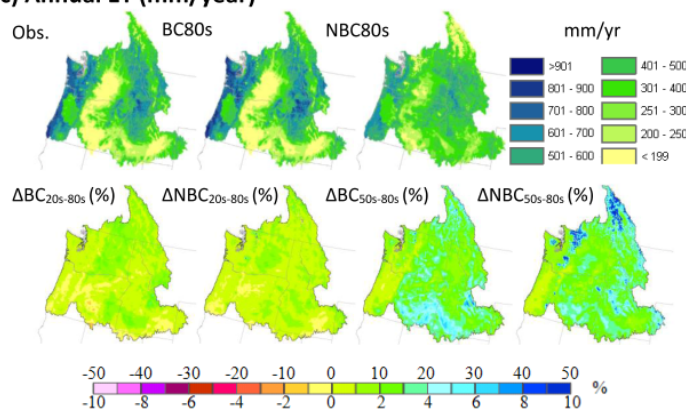

$\Delta \mathrm{BC}_{205-805}(\%)-\Delta \mathrm{NBC}_{205-805}(\%) \quad \Delta \mathrm{BC}_{505-805}(\%)-\Delta \mathrm{NBC}_{505-805}(\%)$
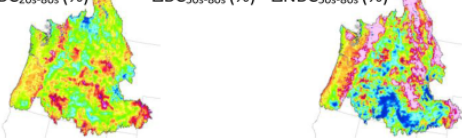

e) SWE on April $1\left(\mathrm{~mm} \mathrm{H}_{2} \mathrm{O}\right)$

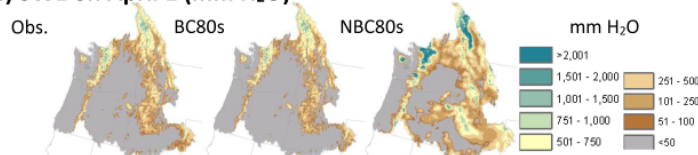

$\triangle \mathrm{BC}_{20 \mathrm{~s}-80 \mathrm{~s}}(\%)>\Delta \mathrm{NBC}_{20 \mathrm{~s}-80 \mathrm{~s}}(\%) \quad \Delta \mathrm{BC}_{50 \mathrm{~s}-80 \mathrm{~s}}(\%) \quad \Delta \mathrm{NBC}_{50 \mathrm{~s}-80 \mathrm{~s}}(\%)$
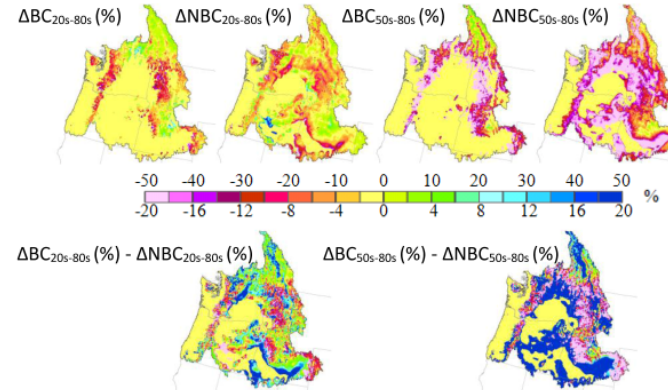

b) Annual Precipitation (mm/year)
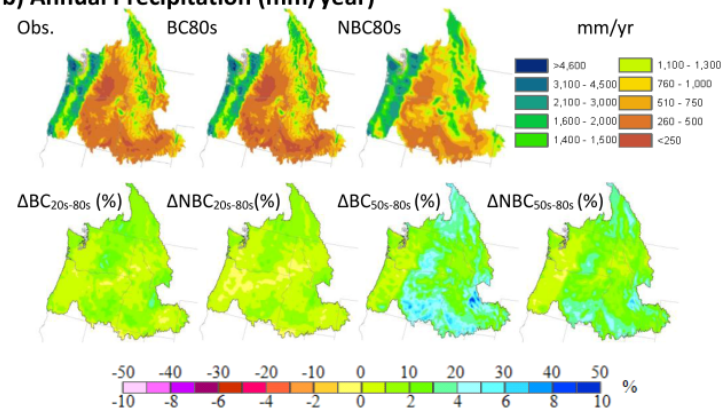

$\Delta B C_{205-805}(\%)-\Delta N B C_{205-805}(\%) \quad \Delta B C_{505-805}(\%)-\Delta N B C_{505-805}(\%)$

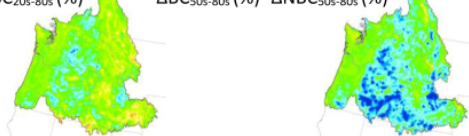

d) Annual Runoff ( $\mathrm{mm} /$ year)
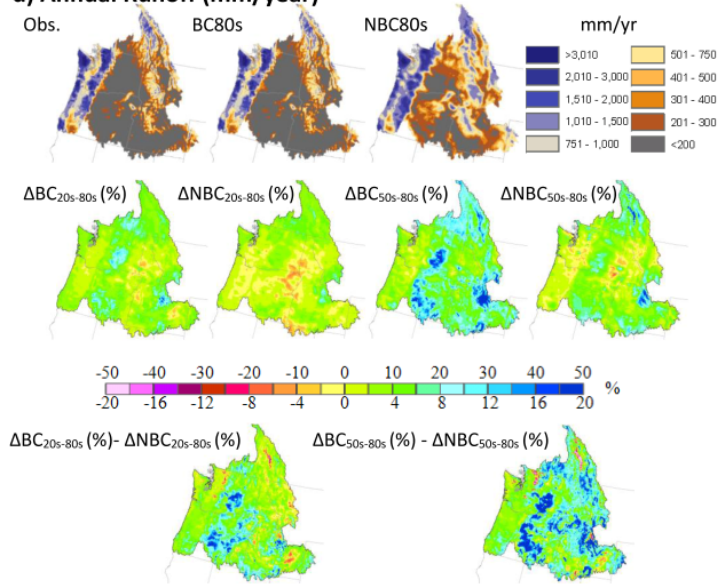

f) Yield (Ton/ha/yr)
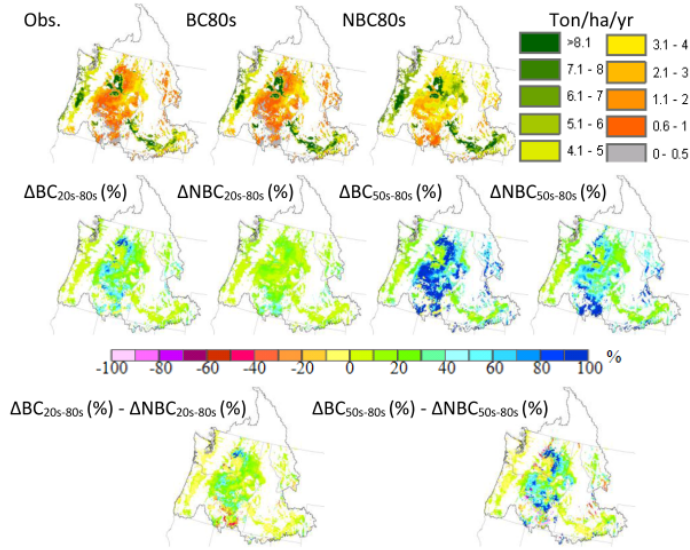

Fig. 5. Spatial patterns of differences in climate and modeled variables driven by observed data (Obs.), bias-corrected (BC), and non-biascorrected (NBC) climate. $\triangle \mathrm{BC}_{20 s-80 s}$ and $\triangle \mathrm{BC}_{50 \mathrm{~s}-80 \mathrm{~s}}$ are total change between the 1980s and 2020s and between the 1980s and 2050s, respectively, under $\mathrm{BC}$ climate. $\triangle \mathrm{BC}_{20 s-80 s}(\%)$ and $\triangle \mathrm{BC}_{50 s-80 s}(\%)$ are the percentage change between the 1980s and 2020s and between the 1980s and 2050s, respectively, and they are calculated as $\Delta \mathrm{BC}_{2020 s} / \mathrm{BC}_{1980 s} \times 100 \%$ and $\Delta \mathrm{BC}_{2050 s} / \mathrm{BC}_{1980 s} \times 100 \%$, respectively. " $\triangle \mathrm{BC}_{20 s-80 s}(\%)-\triangle \mathrm{NBC}_{20 s-80 s}(\%)$ " is the difference in the percentage change between the 1980s and 2020s in simulated results driven by $\mathrm{BC}$ and NBC climate; similarly " $\triangle \mathrm{BC}_{50 s-80 s}(\%)-\triangle \mathrm{NBC}_{50 s-80 s}(\%)$ " is the difference in the percentage change between the 1980s and 2050s. " $\triangle \mathrm{BC}_{20 s-80 s}-\triangle \mathrm{NBC}_{20 s-80 s "}$ is the difference in the total change between the 1980s and 2020s in simulated results driven by $\mathrm{BC}$ and $\mathrm{NBC}$. 


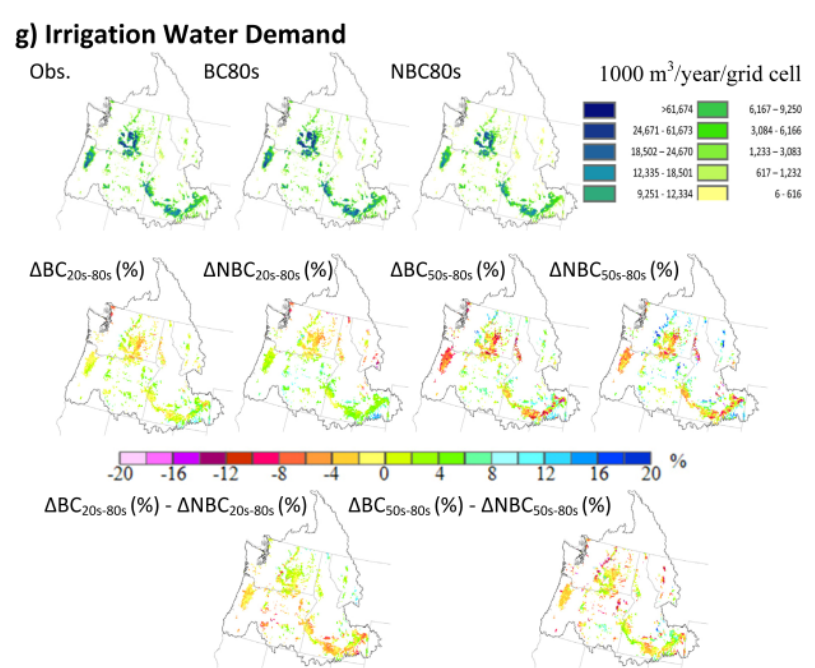

i) Monoterpenes Emission $\left(\mu \mathrm{g} / \mathrm{m}^{2} / \mathrm{hr}\right)$
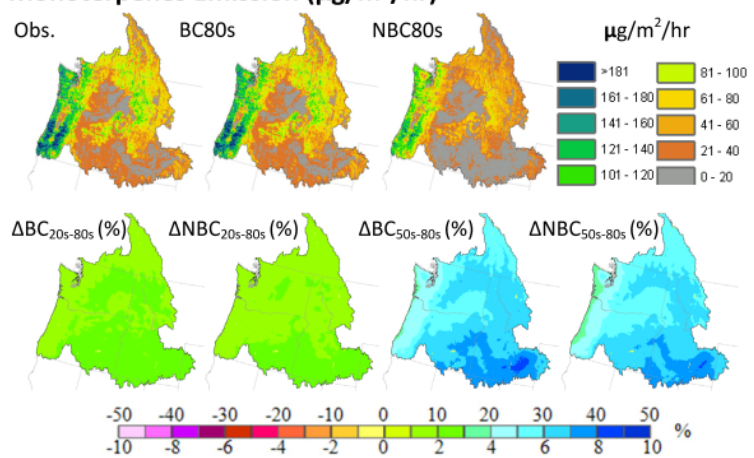

$\Delta B C_{20 s-805}(\%)-\Delta N B C_{205-805}(\%) \quad \Delta B C_{505-805}(\%)-\Delta N B C_{505-805}(\%)$
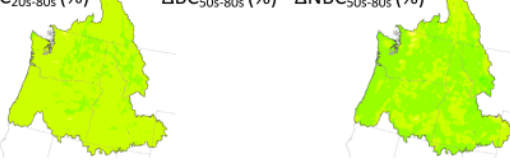

k) Annual ET (mm/yr)

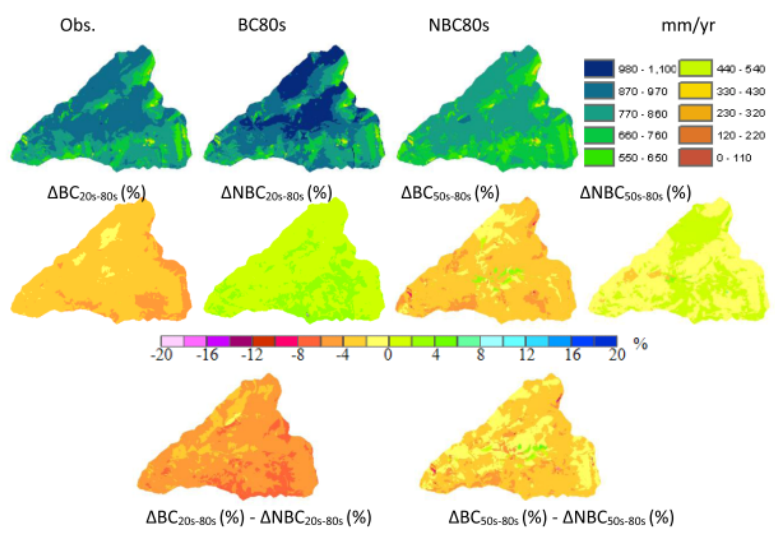

Fig. 5. Continued.

( $p=0.03$ for anomalies in the 2020s and $p<0.001$ for anomalies in the 2050s) and BC treatment affects $94.2 \%$ of the grid cells in estimating relative change in SWE during h) Isoprene Emission ( $\mu \mathrm{g} / \mathrm{m}^{2} / \mathrm{hr}$ )
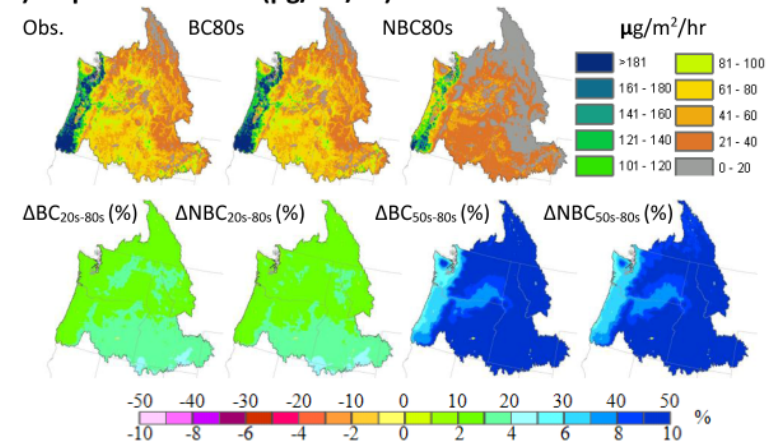

$\Delta \mathrm{BC}_{20 \mathrm{~s}-80 \mathrm{~s}}(\%)-\Delta \mathrm{NBC}_{20 \mathrm{~s}-80 \mathrm{~s}}(\%) \quad \Delta \mathrm{BC}_{50 \mathrm{~s}-80 \mathrm{~s}}(\%)-\Delta \mathrm{NBC} \mathrm{C}_{50 \mathrm{~s}-80 \mathrm{~s}}(\%)$
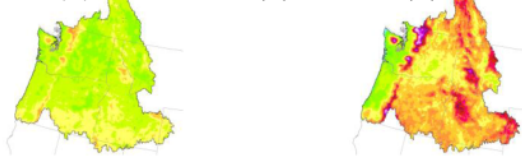

j) NO Emission $\left(\mu \mathrm{g} / \mathrm{m}^{2} / \mathrm{hr}\right)$
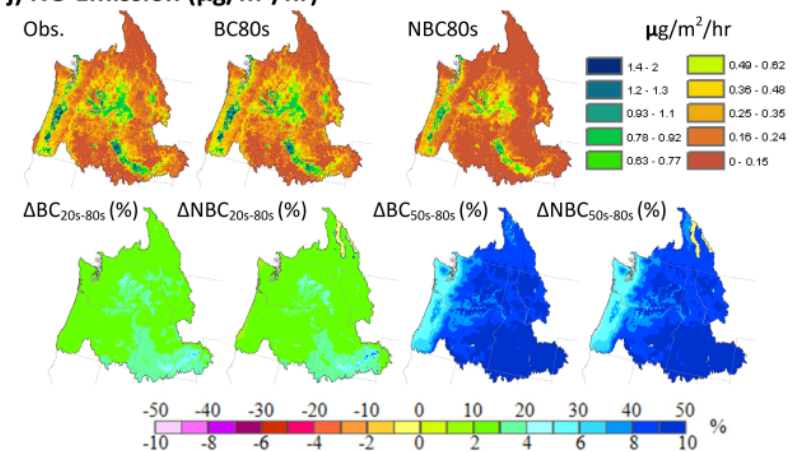

$\Delta B C_{205-80 s}(\%)-\Delta N B C_{205-805}(\%) \quad \Delta B_{505-805}(\%)-\Delta N B C_{505-80 s}(\%)$
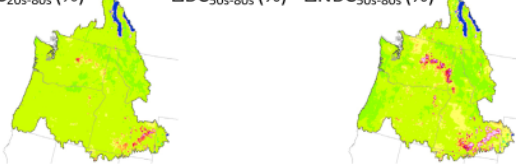

I) Annual NPP (gC/m²/yr)
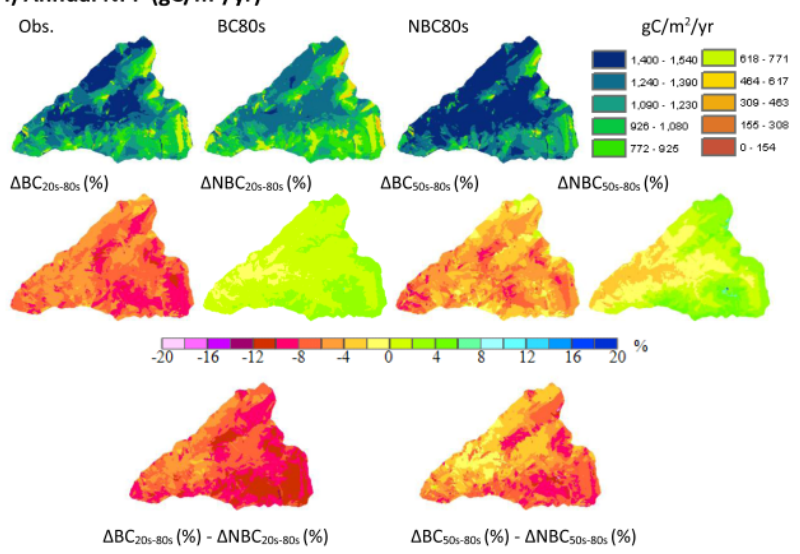

the period of 1980s-2050s (Fig. 3). Our simulations indicate that under hotter and dryer conditions (BC data), continuous warming may have fewer relative impacts on snowpack 
accumulation than under cooler and wetter background conditions (NBC data), particularly over high mountainous areas (Fig. 5e). The SWE of a cooler baseline (NBC data) has more potential to be affected by additional warming as compared to a warmer baseline (BC data) subject to the same additional warming (Fig. 5e), especially if the additional warming moves grid cells from below freezing temperatures to above freezing temperatures. Also, a larger expanse of negligible snowpack areas in the BC scenario as compared to the NBC scenario can result in larger areas being categorized as having no change in SWE for the BC scenario.

\subsubsection{Impacts on croplands (VIC-CropSyst simulations)}

Crop yield and irrigation water demand are important factors in a farmer's decision-making process. In the study domain, over 40 types of crops, including tree fruits, grains, cereals, vegetables, and crops for forage are simulated by VIC-CropSyst. The crop yield in each grid cell and the regional mean crop yield are calculated as area-weighted average yields in this analysis (Fig. 5f).

\section{Crop yield}

BC has a large effect on estimated crop yield by VICCropSyst. Over the historical period, the total crop yield from BC and observed climate data are similar (31.1 and 29.6 million tons (Mt), respectively), while the NBC climate data resulted in a much higher crop yield (46.1 Mt) (Table 2). The major difference in estimated yields among NBC, BC, and observed climate data occurs over dryland (non-irrigated) crops (Fig. 5f). Both BC- and NBC-projected climate cause large increases in total yield between present-day and the 2020s or 2050s (Table 2, Fig. 5f). In contrast to the projections for dryland crops, $\mathrm{BC}$ does little to change yield projections for irrigated crops (Table 2; Figs. 3, 4, 5f and g). The behavior of aggregate yields is the net response of multiple crop types that can have different responses to climate change. In addition to the relative increases in temperature, crop yields can be affected by the actual magnitude of temperature itself, which can lead to differences in responses in a cooler NBC scenario versus a warmer BC scenario. The warmer $\mathrm{BC}$ scenario can have a longer available growing season than the cooler NBC scenario, leading to higher relative yield increases in crop types that can take advantage of multiple cuttings. The warmer BC scenario can also have lower relative yield increases in crops that are harvested just once in the season by an accelerated growing degree-day accumulation. In addition, for dryland crops, a higher relative increase in precipitation can lease to higher relative increases in yields. Irrigated crop growth is simulated assuming that there is no water limitation and differences in yields tend to be lower than that of dryland crops.

\section{Water demand (WD) over the irrigated area}

Water demand is defined as the irrigation water required by crops to reach their potential yield. Observed, BC, and NBC climate produce significantly different estimates on water demand during the 1980 s, i.e. $21.31,25.36$, and 17.75 billion $\mathrm{m}^{3}$ per year, respectively (Table 2). Over the entire PNW, both BC and NBC climate data predict insignificant changes in WD during periods of 1980s-2020s and 1980s-2050s (Table 2, Figs. 3 and 4). However, there are large spatial variations in projected WD changes over these periods (Fig. 5g). Generally, WD decreases in central Washington and southern Idaho during the 2020s. In the 2050s, the irrigated areas near the mountains show an increase in WD, whereas there are strong decreases elsewhere, particularly when NBC climate data are used (Fig. 5g). The magnitude and variations of WD depend on changes in ET and $P$. With a higher projected $P$, the PNW has a slight decrease in WD over of the PNW. Because BC data predict a lower ET increase and a higher $\mathrm{P}$ increase, they project a much lower WD during the 2050s period than when using NBC data.

\subsubsection{Impacts on biogenic VOC and NO emissions (MEGAN simulations)}

One of several mechanisms by which climate change affects air quality is by changing emissions of ozone and aerosol precursors, such as isoprene, monoterpene, and nitrogen oxides nitrogen oxides $\left(\mathrm{NO}_{\mathrm{x}}=\mathrm{NO}+\mathrm{NO}_{2}\right)$, from the terrestrial ecosystems. Under projected warmer PNW climate, isoprene, monoterpenes, and NO emissions are expected to increase from current emission levels as they are highly dependent on $T$ (Guenther et al., 2012). The observed climate resulted in annual and area-averaged isoprene emissions of $67 \mu \mathrm{g} \mathrm{m}^{-2} \mathrm{~h}^{-1}$ over the simulation domain (Table 2). The highest emissions ( $>120 \mu \mathrm{g} \mathrm{m}^{-2} \mathrm{~h}^{-1}$ ) occur in the coniferdominated forests on the western side of the Cascade Mountains, where temperatures are also the highest (Fig. 5h). The lowest emissions occur in high-elevation areas, where temperatures are lowest (Fig. 5h). The magnitude of annual monoterpene emissions is on the same order as isoprene emissions (59 $\mathrm{g} \mathrm{m}^{-2} \mathrm{~h}^{-1}$ for the whole domain) (Table 2). The highest monoterpene emissions appear on the west side of the Cascades, while the lowest occur in central and southern part of the domain, which are dominated by crop, shrub, and grasslands (Fig. 5i). NO emissions are the highest over the agricultural areas, with an average rate of $0.3 \mu \mathrm{g} \mathrm{m}^{-2} \mathrm{~h}^{-1}$ over the whole domain (Fig. 6j).

Driven by BC climate data, MEGAN estimates slightly lower isoprene, monoterpenes, and $\mathrm{NO}$ emission rates by $1.2 \%$ than by observed meteorological data (Table 2). In contrast, when compared to observed meteorological data, NBC climate underestimates isoprene, monoterpenes, and NO emissions by 49,31 , and $36 \%$, respectively. 

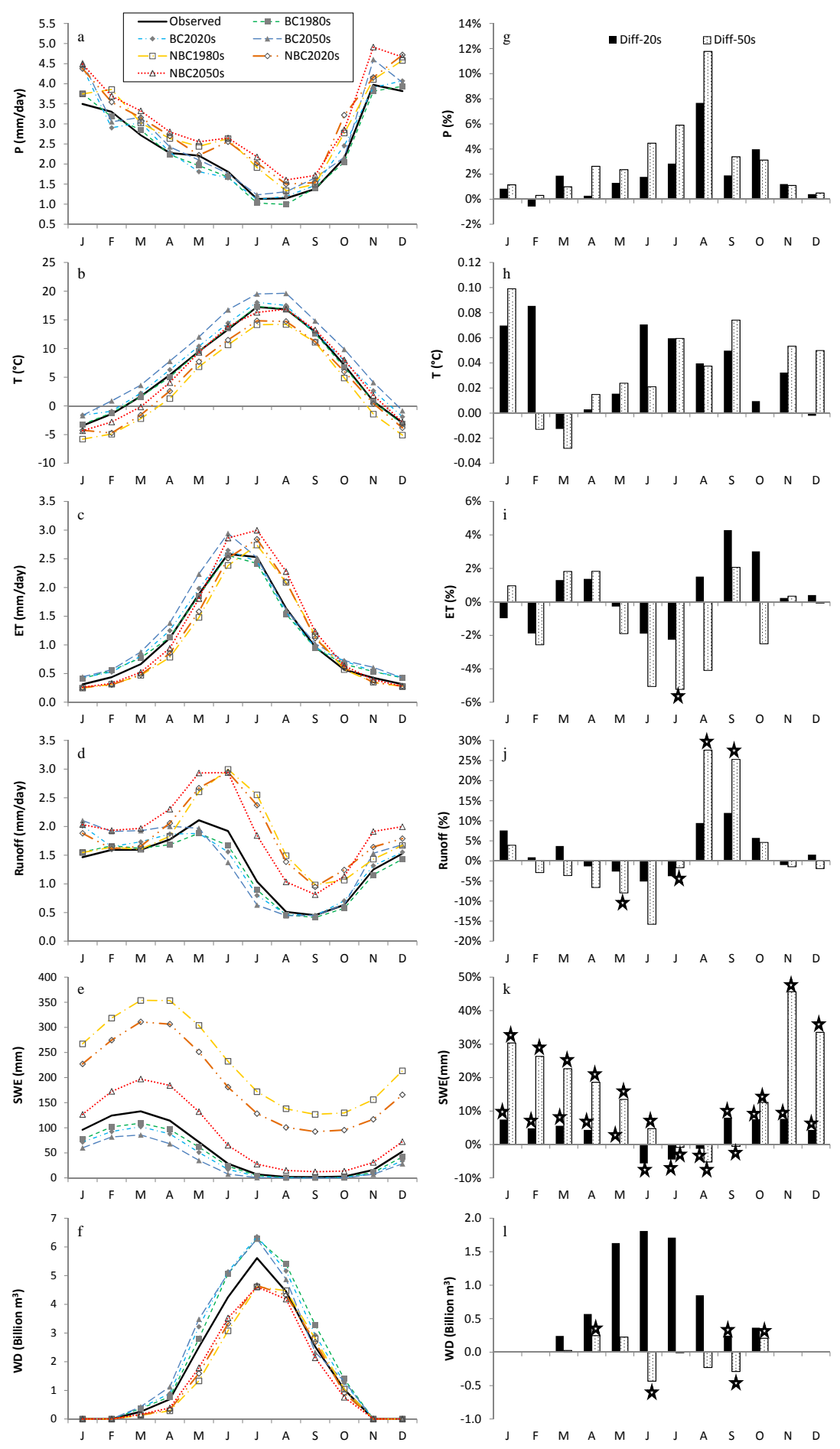

Fig. 6. Seasonal patterns of differences in climate and simulated hydrological variables driven by bias-corrected (BC) and non-biascorrected (NBC) data. The left column is monthly mean (from January to December) over different scenarios and time periods; the right column is the differences between BC- and NBC climate and modeled variables in two periods, i.e., 2020s-1980s and 2050s1980s. The unit of water demand (WD) is billion $\mathrm{m}^{3}$. Note: plotted for precipitation, ET, runoff, and SWE are differences in percentage changes, i.e., $\left(\triangle \mathrm{BC}_{20 s-80 s} / \mathrm{BC}_{1980 s} \times 100 \%\right)-\left(\Delta \mathrm{NBC}_{20 s-80 s} / \mathrm{NBC}_{1980 s} \times 100 \%\right)$ for changes between $1980 \mathrm{~s}$ and $2020 \mathrm{~s}$ and $\left(\triangle \mathrm{BC}_{50 s-80 s} / \mathrm{BC}_{1980 s} \times 100 \%\right)-\left(\triangle \mathrm{NBC}_{50 s-80 s} / \mathrm{NBC}_{1980 s} \times 100 \%\right)$ for changes between the 1980s and 2050s; plotted for temperature and water demand are differences in absolute changes, i.e., $\Delta \mathrm{BC}_{20 s-80 s}-\Delta \mathrm{NBC}_{20 s-80 s}$ for changes between the 1980s and 2020s and $\triangle \mathrm{BC}_{50 s-80 s}-\triangle \mathrm{NBC}_{50 s-80 s}$ for changes between the 1980s and 2050s. The small stars under or above each column mean $p$ value $<0.05$ for the Student $t$ test of differences between BC anomalies and NBC anomalies for each month. 
Both $\mathrm{BC}$ and $\mathrm{NBC}$ cases project increasing emission trends in future climate, but the projected emission rates vary significantly. For example, isoprene emission is projected to increase from $65 \mu \mathrm{g} \mathrm{m}^{-2} \mathrm{~h}^{-1}$ in the $1980 \mathrm{~s}$ to $75 \mu \mathrm{g} \mathrm{m}^{-2} \mathrm{~h}^{-1}$ in the 2020 s with BC climate vs. $33 \mu \mathrm{g} \mathrm{m}^{-2} \mathrm{~h}^{-1}$ in the $1980 \mathrm{~s}$ to $38 \mu \mathrm{g} \mathrm{m}^{-2} \mathrm{~h}^{-1}$ in the 2020 s with NBC climate. Even though the magnitude of the estimated emission rates differ by a factor of 2 , the projected percent increases are similar. Isoprene, monoterpene, and $\mathrm{NO}$ emissions are projected to increase by 14,9 , and $10 \%$ during $1980 \mathrm{~s}-2020 \mathrm{~s}$ and increase by 43,28 , and $13 \%$ during 1980 s-2050s, respectively, under both $\mathrm{BC}$ and $\mathrm{NBC}$ climate. Hence, in comparison to other CCI variables, $\mathrm{BC}$ has a small effect on the climate change signal for the biogenic emissions considered in this study (Table 2).

\subsubsection{Impacts on export of DIN from the land to the ocean (NEWS simulations)}

The concentration of DIN in streams and reservoirs is an important indicator for water quality and health of aquatic ecosystems. In this study, Global NEWS simulates the DIN export from the CRB, which covers $85 \%$ of the study domain (Fig. 1). For the 1980s, NEWS estimates an average DIN yield (that is, the average DIN leaching from the land that is eventually exported to the ocean) of 92,101 , and $154 \mathrm{~kg}$ $\mathrm{N} \mathrm{km}^{-2}$ year ${ }^{-1}$, using observed, $\mathrm{BC}$, and NBC climate inputs, respectively (Table 2). Both $\mathrm{BC}$ and NBC climate inputs result in predicted increases in DIN export for the 2020s and the 2050s, which closely match changes in $P$ and runoff (Table 2). Using NBC climate data results in somewhat lower percentage increases $(+3.6$ and $+7.3 \%$ for the 2020 s and 2050s, respectively), although the differences are not statistically significant ( $p>0.7$ for all periods examined) (Figs. 3 and 4). Overall, variations of DIN yield and its transport are highly correlated with changes in $P$ because $P$ influences runoff, which in turn affects the efficiency with which DIN is transferred from soils to surface waters, and subsequently downstream to the coast (Table 2). Of course, temperature and irrigation demand also have the potential to influence runoff, but the effects of each of these drivers appear to be smaller than the effect of precipitation over the region and time period examined.

\subsubsection{Impacts on water and carbon fluxes in a small forested watershed}

\section{Evapotranspiration}

For this small watershed study site, HJ-Andrews, observed meteorological data, and $\mathrm{BC}$ and $\mathrm{NBC}$ estimates give similar $P$ for the 1980 s baseline. NBC data, however, indicate substantially lower $T\left(6.6\right.$ and $9{ }^{\circ} \mathrm{C}$ from NBC and observed data, respectively). By using observed, $\mathrm{BC}$, and $\mathrm{NBC}$ climate data, RHESSys estimates the mean annual ET to be 831,876 , and $743 \mathrm{~mm}$ year $^{-1}$, respectively, for the 1980 s. The lower $T$ in NBC climate data $\left(6.6^{\circ} \mathrm{C}\right)$ results in lower modeled ET (Table 2). For the projection of future $\triangle \mathrm{ET}(\%), \mathrm{BC}$ and NBC climate produce significant differences over the period of the 2020s (Figs. 4 and 5, $p=0.02$ ); that is, using BC climate data leads to a decrease of $3.3 \%$, while using NBC data leads to an increase of $1.6 \%$ (Table 2, Fig. 6k). In comparing ET in the 2050s relative to the 1980s baseline, the BC case predicts a lower ET by $2.7 \%$, while the NBC case shows no significant change in ET (Table 2, Fig. 6k). RHESSys results indicate that differences and changes in $P$ over the wet regions have no significant effects on the estimated ET, while the difference in $T$ baseline could lead to significant differences.

\section{Net primary production}

NPP is commonly used to provide an estimate of the carbon gained by an ecosystem and develop a carbon balance between the terrestrial biosphere and the atmosphere (Chapin et al., 2002; Clark et al., 2001). In HJ-Andrews, NBC climate data (colder) produce higher NPP than BC (warmer) and observed climate data (warmer) during the 1980s (Table 2). Following the $\triangle \mathrm{ET}(\%)$, using $\mathrm{BC}$ and $\mathrm{NBC}$ inputs result in large differences in modeled $\triangle \mathrm{NPP}(\%)$. With BC climate data, RHESSys predicts decreases in NPP by 6.5 and $4.4 \%$ during the periods of $1980 \mathrm{~s}-2020 \mathrm{~s}$ and $1980 \mathrm{~s}-2050 \mathrm{~s}$, respectively (Table 2). In contrast, using NBC climate data, RHESSys predicts slight increases in NPP for both future periods (Table 2, Fig. 61). Although the differences in modeled NPP as a function of differences between BC and NBC climate are not statistically significant ( $p=0.12$ and 0.46 for the 2020s and 2050s, respectively), they show a clear spatial pattern. Figure 61 shows that large differences in estimated $\triangle \mathrm{NPP}(\%)$ between BC and NBC climate data are concentrated at higher elevations, whereas the NBC case predicts increases while BC results in decreases. This result may indicate that contemporary warmer temperatures in the region (i.e., observed and $\mathrm{BC}$ climate data) have reached a critical threshold where further increases in $T$ will cause decreases in NPP. Conversely, under cooler conditions (NBC data), warming can still enhance vegetation productivity, especially at higher elevations.

\subsection{Impact of $\mathrm{BC}$ in estimates of seasonal patterns}

To investigate the seasonal shift of CCI on water resources, we analyze the monthly water fluxes and water demand by using VIC offline and VIC-CropSyst simulations (Fig. 2). 

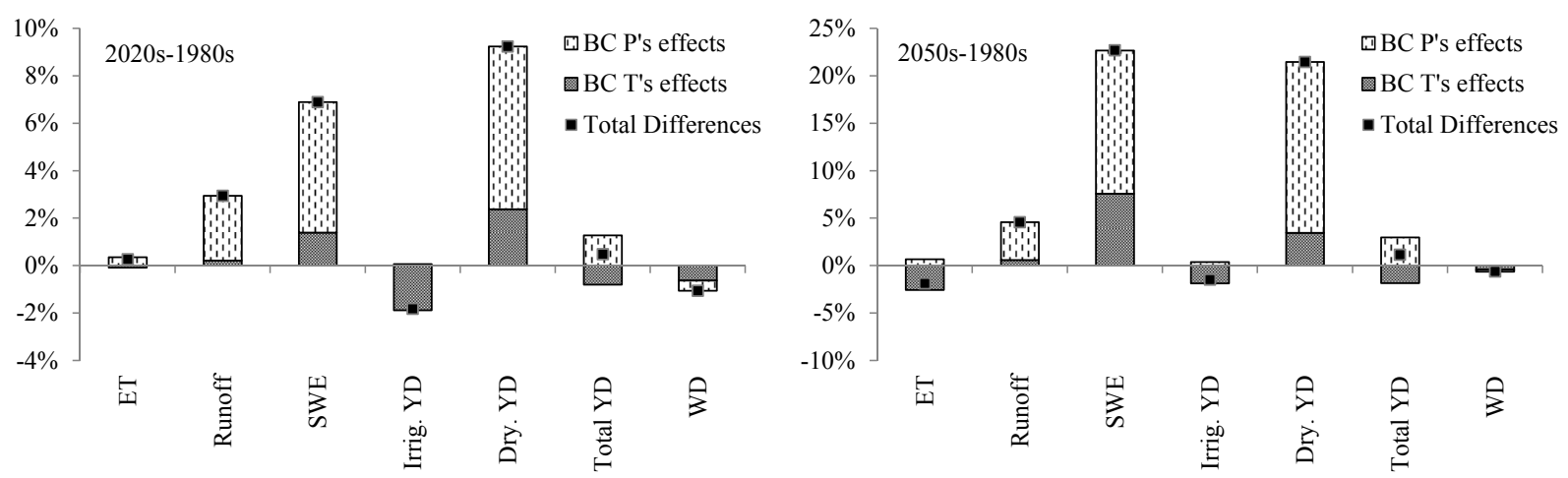

Fig. 7. Contributions of bias corrections (BC) on temperature $(T)$ (Eq. 5) and precipitation $(P)$ (Eq. 7) to the total differences (Eq. 3) of modeled changes in major hydrologic variables and crop yield between BC and NBC climate driving forces. Left panel: changes between the 1980s and 2020s; right panel: changes between the 1980s and 2050s. ET: average annual evapotranspiration; Runoff: total runoff; SWE: snowpack water equivalent on 1 April; Total YD: total yield from all croplands; Irrig. YD: yield from irrigated cropland; Dry. YD: yield from dryland (non-irrigated cropland); WD: total irrigation water demand over irrigated cropland.

\subsubsection{Differences in $\mathrm{BC}$ and $\mathrm{NBC}$ climate data}

Figure 6 depicts the average monthly climate $(P \& T)$, simulated water fluxes (ET and runoff), SWE, and water demand (WD) with different climate data and periods. BC and NBC climate data exhibit large discrepancies in summer $P$, while they have similar patterns in monthly $T$ (Fig. $6 \mathrm{a}$ and b). BC data for $\Delta P(\%)$ result in greater increases than for NBC data in almost every month, particularly between May and October (Fig. 6g). However, the difference between BC and NBC $\Delta P(\%)$ is not statistically significant $(p>0.05)$ due to large interannual variations in monthly $P$. BC and NBC cases show only small discrepancies in predictions of monthly $\Delta T$ over the periods of 1980s-2020s and 1980s2050s (Fig. 6h).

\subsubsection{Seasonal patterns of discrepancies between BC and NBC climate-data-driven changes in water fluxes}

Figure 6d demonstrates that using NBC climate data (in comparison to $\mathrm{BC}$ and observed data) result in a large overestimation of runoff from May to August due to the high SWE for this scenario. Lower $T$ and higher $P$ for the NBC case (relative to the $\mathrm{BC}$ case) result in a larger area of snow cover as well as larger snowpack volumes (Fig. 6e). Irrigation WD is greater for the BC case than for NBC, particularly from May to August, mostly due to the much higher projected NBC $P$ (Fig. 6a and f).

The differences in predicted percentage change in ET, runoff, SWE, and WD driven by $\mathrm{BC}$ and $\mathrm{NBC}$ climate data vary seasonally, as depicted in the right panel of Fig. 6. Generally, use of BC (vs. NBC) climate data leads to lower $\triangle \mathrm{ET}$ (\%) for the months of June-August in the 2050s (Fig. 6i). However, the differences are not statistically significant except for 2050s July ( $p=0.04$ ) (Fig. 6i). Use of BC (vs. NBC) produces significant discrepancies in many months for longterm predictions of $\Delta$ Runoff (\%) (Fig. 6j); for example, using 2050s BC climate results in higher $\Delta$ Runoff (\%) in August $(p<0.001)$ and September $(p<0.001)$ by more than $25 \%$, whereas this difference is negative for most of the other months. We report very large differences in monthly $\triangle \mathrm{SWE}$ (\%) projections, which are much larger for the 2050s period than for the 2020s (Fig. 6k). BC results in larger SWE increases (in comparison to NBC) throughout the cold season, particularly for the 2050s. For changes in irrigation water demand, $\triangle \mathrm{WD}(\%), \mathrm{BC}$ climate results in much larger increases than NBC for the 2020s, although this increase is significant only for September (Fig. 7l). While the magnitude of these differences between $\mathrm{BC}$ and $\mathrm{NBC}$ is smaller for the 2050s and vary by month in the sign of this difference, they are generally statistically significant.

\subsection{Relative contributions of $T$ and $P$ to the overall differences between $\mathrm{BC}$ and $\mathrm{NBC}$ climate change impacts}

We separate out the individual roles of $T$ and $P$ to differences between climate change projections using $\mathrm{BC}$ versus NBC input data sets (Table 1). These tests showed that BC post-processing of WRF-simulated $P$ plays a more important role than $\mathrm{BC}$ post-processing of $T$ in impacting changes in runoff, SWE, and dryland crop yield; that is, using NBC $P$ for CCI analyses can lead to underestimation of the increases in runoff and dry land crop yield and overestimation of the decrease in SWE (Fig. 7). Figure 7 also demonstrates that BC of $T$ is the dominant factor in causing the BC and NBC differences in the projected changes of irrigated crop yield (recall that over irrigated cropland, we assume that all crop water requirements are met, reducing the potential role of $P$ ) in the 2020s and 2050s and long-term ET changes in 

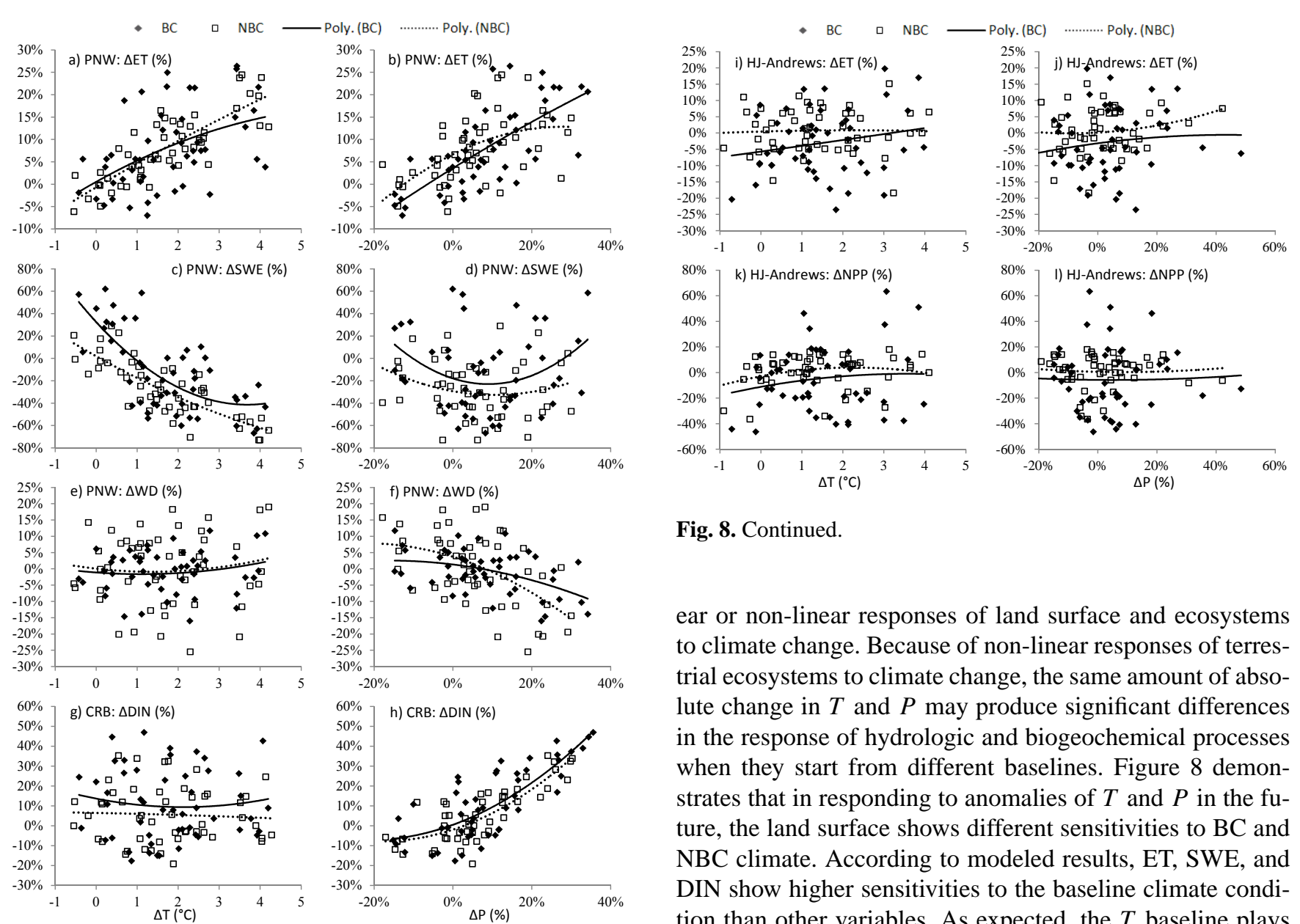

Fig. 8. Continued.

ear or non-linear responses of land surface and ecosystems to climate change. Because of non-linear responses of terrestrial ecosystems to climate change, the same amount of absolute change in $T$ and $P$ may produce significant differences in the response of hydrologic and biogeochemical processes when they start from different baselines. Figure 8 demonstrates that in responding to anomalies of $T$ and $P$ in the future, the land surface shows different sensitivities to $\mathrm{BC}$ and NBC climate. According to modeled results, ET, SWE, and DIN show higher sensitivities to the baseline climate condition than other variables. As expected, the $T$ baseline plays a strong role in determining SWE changes (Fig. 8c), while DIN changes are most sensitive to $P$ gradients (Fig. 8h), and ET changes are equally sensitive to gradients in both $T$ and $P$ (Figs. 8a and b). Furthermore, BC and NBC climates produce different response curves for each of the impact variables. For example, with increasing $T$, using NBC climate data produces a linearly increasing trend in total ET, while using $\mathrm{BC}$ climate data results in a relative levelingoff of changes at high- $T$ anomalies over the PNW (Fig. 8a); with increasing $P, \mathrm{NBC}$ shows a leveling-off in increasing ET, while NB climate predicts a continuing linear increase along with increased $P$ (Fig. 8b). The responding curve, however, is spatial-explicit and scale-depended. For instance, The slope of the response curve of ÄET to ÄT and ÄP over the small watershed (i.e. HJ-Andrews) is much smaller than that over the entire PNW, while the difference in responding to $\mathrm{BC}$ and NBC climate data is larger over the small watershed than the entire region (Fig. 8a-b and $\mathrm{i}-\mathrm{j}$ ). These results indicate that the responses of the land surface to climate change depend on the magnitude of the change, the baseline climate, and location. the 2050s, indicating a primarily energy-limited ET regime (Liu et al., 2013).

The impact of BC and NBC depends on the distance of baseline and climate change to environmental threshold (e.g., $0{ }^{\circ} \mathrm{C}$ for snowpack accumulations) that determines the lin- 


\section{Discussion}

Our analysis indicates that the choice of bias correcting or not bias correcting downscaled global GCM projected climate could affect estimates of climate change impacts in the future. Non-linear responses of hydrologic and biogeochemical processes to climate change can partly explain this phenomenon. The spatial variations in different quasi-equilibria among local biotic and abiotic environments such as climate, vegetation, geology, topology, etc. introduce more complexities into these uncertainties in regional assessments. Therefore, when using projected results from GCM and regional climate models, uncertainty analysis should be conducted, particularly in situations where some post-processing procedures such as BC, which is based on contemporary observational data, are involved.

Unrealistic land surface responses from not performing $\mathrm{BC}$ of modeled climate prior to driving impact models may be obvious in some cases. Failing to account for BC impacts on snow processes could produce misleading projections on future water availability, an issue of importance to both ecosystems and society. Using BC (vs. NBC) climate data in our study would result in fewer perceived threats to society and ecosystems, less shrinkage of the snowpack, higher crop yields, and lower water demand. Furthermore, while our study suggested that BC may not be necessary for projecting the impacts of climate change on the magnitude of some biogenic emissions, there are important air quality implications to not performing BC. For example, underestimation of biogenic VOCs emissions may affect the prediction of ozone as well as secondary organic aerosol (SOA) and thus fine particulate matter $\left(\mathrm{PM}_{2.5}\right)$ concentrations, with ozone and $\mathrm{PM}_{2.5}$ concentrations being the key decisionmaking variables for air quality management. Assessing how bias in climate model results affects projected changes in ozone, SOA, and $\mathrm{PM}_{2.5}$ requires detailed analysis with the use of chemical transport models that not only accounts for changing emission rates but also explicitly simulate the nonlinear, meteorology-dependent atmospheric chemistry, transport, and deposition processes. To our knowledge, no techniques have been developed to bias correct three-dimensional RCM output, and therefore no studies have applied bias correction to the input of chemical transport models.

As often the case, CCI simulations performed here use models that are run offline from each other and thus feedbacks between subcomponents of the Earth system are not addressed. The following are some examples of feedbacks to the atmosphere that are not are considered in CCI studies of this kind: ET and WD affect soil moisture and thus latent heat transfer, SWE affects surface albedo and thus radiation, VOC and $\mathrm{NO}_{\mathrm{x}}$ affect SOA formation and thus aerosolradiation and aerosol-cloud-precipitation interactions, and NPP affects carbon and thus atmospheric $\mathrm{CO}_{2}$ levels. Indeed, not accounting for feedbacks may contribute to some of the biases that have necessitated the need for bias correction in the first place. To consider these feedbacks requires fully coupled models for which bias correction would break fundamental laws of physics, defeating the purpose of processbased models. Coupled models are useful for formulating hypotheses on which of the feedback processes have important consequences for decision-making variables and for designing experimental studies that can quantify these feedbacks and improve models.

There are other limitations in this study. For example, we only quantified the effects of $\mathrm{BC}$ of $T$ and $P$ on CCI of regional hydrology, agricultural activities, DIN export, and biogenic VOC and NO emissions. Other related climate factors including wind speed, relative humidity, and radiation are either based on reanalysis data or modeled by the VIC model (Hamlet et al., 2007; Maurer et al., 2002; Salathe et al., 2013). Even though the derived climate factors from $T$ and $P$ by using MT-CLIM model have been evaluated against field observations (Bohn et al., 2013; Thornton and Running, 1999), the spatiotemporal relationships within climate variables in contemporary periods may change over the long-term future. Therefore, by only using information of $T$ and $P$ changes, CCI studies may produce large uncertainties. Each bias correction and downscaling approach may have individual strengths and weaknesses in reconstructing the spatial and temporal patterns of $T$ and $P$, as well as extreme events (Maurer and Hidalgo, 2008; Quintana Segui et al., 2010; Themessl et al., 2011). Estimating the sensitivities of different downscaling methods on hydrologic and ecological impacts is meaningful and necessary for quantifying the uncertainties from certain downscaled climate data in regional applications. This effort could be an extension of current intercomparisons on global GCMs and activities on modeldata intercomparisons over carbon, water, and crops at continental and global scales (Asseng et al., 2013; Huntzinger et al., 2012; Rosenzweig et al., 2013; Taylor et al., 2012).

\section{Conclusions}

Herein, we quantify the effects of bias correction of climate model output on climate change impact projections of regional and watershed-scale hydrologic and biogeochemical processes. As expected (due to the BC methodology), using $\mathrm{BC}$ climate data produced almost the same simulated results as using gridded meteorological observations for the historical time period. Without BC, however, the direct use of modeled climate data by land surface models produced very different hydrologic and biogeochemical results over the historical period. While we anticipated that these differences would be large, an interesting question is the degree to which the response to a climate change signal is preserved, even if the baseline climate conditions are not. This is an important question because, in fully coupled land-atmosphere schemes, BC is generally not performed, so that dynamical consistency in simulated variables is retained. In doing this, 
a fundamental assumption is that models can predict the relative change of a variable of interest in response to climate change reasonably well, even if model prediction of the actual value of the variable is biased. Herein, we test whether or not this assumption holds true and for which land surface variables.

Due to the conservation of absolute change of $T$ and percentage rate of change in $P$ during $\mathrm{BC}$ post-processing, projected $\mathrm{BC}$ and NBC climate data produce somewhat similar results in the percentage rate of change in many of our response variables, including ET, runoff, total crop yield, irrigated water demand, VOC emissions (isoprene and monoterpenes), NO emission, and DIN river export over the PNW over the time periods of $1980 \mathrm{~s}-2020 \mathrm{~s}$ and $1980 \mathrm{~s}-2050 \mathrm{~s}$. However, there a few important variables for which $\mathrm{BC}$ does have a large impact in the response to climate change, notably SWE and dryland (non-irrigated) crop yield. Both of these variables are key decision variables for managing our natural and agricultural resources. Overall, not performing $\mathrm{BC}$ would result in an overestimation of the decrease of SWE and an underestimation of the increase in dryland crop yield due to climate change, thus painting a more dire portrait of future conditions than would be suggested by using $\mathrm{BC}$ data. Considering all variables under $\mathrm{BC}$ in projecting responses to climate change, there is the potential for a large range of effects when performing land surface simulations with biased climate inputs.

We conclude that there are trade-offs between using BC climate data for offline CCI studies versus applying coupled regional Earth system models that retain dynamical consistency between variables and capture feedback effects. These trade-offs should be considered when designing integrated modeling frameworks for specific applications; for example, BC may be more important when considering impacts on reservoir operations in mountainous watersheds (where 1 April SWE is an important decision factor) than when investigating impacts on biogenic emissions and air quality (where VOCs are a primary indicator). However, even in these instances where BC may not be deemed important, there may be some important negative consequences to not correcting for bias, such as a host of air quality effects and aerosol-radiation-cloud interactions caused by projecting biased values of biogenic emissions.

Acknowledgements. This study has been supported by the United States Department of Agriculture (grant no. 20116700330346 for the Biosphere-relevant Earth system modeling project, BioEarth) and the National Science Foundation (grant no. 0903714 for Nitrogen Systems: Policy-oriented Integrated Research and Education program, NSPIRE).

Edited by: S. M. Noe

\section{References}

Adam, J. C., Hamlet, A. F., and Lettenmaier, D. P.: Implications of global climate change for snowmelt hydrology in the twenty-first century, Hydrol. Proc., 23, 962-972, 2009.

Adam, J. C., Stephens, J. C., Chung, S. H., Brady, M. P., Evans, R. D., Kruger, C. E., Lamb, B. K., Liu, M. L., Stöckle, C. O., Vaughan, J. K., Rajagopalan, K., Harrison, J. A., Tague, C. L., Kalyanaraman, A., Chen, Y., Guenther, A., Leung, F. Y., Leung, L. R., Perleberg, A. B., Yoder, J., Allen, E., Anderson, S., Chandrasekharan, B., Malek, K., Mullis, T., Miller, C., Nergui, T., Poinsatte, J., Reyes, J., Zhu, J., Choate, J. S., Jiang, X., Nelson, R., Yoon, J. H., Yorgey, G. G., Johnson, K., Chinnayakanahalli, K. J., Hamlet, A. F., Nijssen, B., and Walden, V.: BioEarth: Envisioning and developing a new regional earth system model to inform natural and agricultural resource management, Clim. Change, doi:10.1007/s10584-014-1115-2, 2014.

Andreadis, K. M., Storck, P., and Lettenmaier, D. P.: Modeling snow accumulation and ablation processes in forested environments, Water Resour. Res., 45, W05429, doi:10.1029/2008WR007042, 2009.

Asseng, S., Ewert, F., Rosenzweig, C., Jones, J. W., Hatfield, J. L., Ruane, A. C., Boote, K. J., Thorburn, P. J., Rotter, R. P., Cammarano, D., Brisson, N., Basso, B., Martre, P., Aggarwal, P. K., Angulo, C., Bertuzzi, P., Biernath, C., Challinor, A. J., Doltra, J., Gayler, S., Goldberg, R., Grant, R., Heng, L., Hooker, J., Hunt, L. A., Ingwersen, J., Izaurralde, R. C., Kersebaum, K. C., Muller, C., Naresh Kumar, S., Nendel, C., O/'Leary, G., Olesen, J. E., Osborne, T. M., Palosuo, T., Priesack, E., Ripoche, D., Semenov, M. A., Shcherbak, I., Steduto, P., Stockle, C., Stratonovitch, P., Streck, T., Supit, I., Tao, F., Travasso, M., Waha, K., Wallach, D., White, J. W., Williams, J. R. and Wolf, J.: Uncertainty in simulating wheat yields under climate change, Nature Clim. Change, 3, 827-832, 2013.

Avise, J., Chen, J., Lamb, B., Wiedinmyer, C., Guenther, A., Salathé, E., and Mass, C.: Attribution of projected changes in summertime US ozone and PM2.5 concentrations to global changes, Atmos. Chem. Phys., 9, 1111-1124, doi:10.5194/acp9-1111-2009, 2009.

Avise, J., Abraham, R. G., Chung, S. H., Chen, J., Lamb, B., Salathe, E. P., Zhang, Y., Nolte, C. G., Loughlin, D. H., Guenther, A., Wiedinmyer, C., and Duhl, T.: Evaluating the effects of climate change on summertime ozone using a relative response factor approach for policymakers, J. Air Waste Manage. Assoc., 62, 1061-1074, 2012.

Barnett, T., Adam, J., and Lettenmaier, D.: Potential impacts of a warming climate on water availability in snow-dominated regions, NATURE, 438, 303-309, 2005.

Berg, P., Haerter, J. O., Thejll, P., Piani, C., Hagemann, S., and Christensen, J. H.: Seasonal characteristics of the relationship between daily precipitation intensity and surface temperature, J. Geophys. Res.-Atmos., 114, D18102, doi:10.1029/2009JD012008, 2009.

Bohn, T. J., Livneh, B., Oyler, J. W., Running, S. W., Nijssen, B., and Lettenmaier, D. P.: Global evaluation of MTCLIM and related algorithms for forcing of ecological and hydrological models, Agr. Forest. Meteorol., 176, 38-49, 2013.

Bouwman, A. F., van Grinsven, J. J. M., and Eickhout, B.: Consequences of the cultivation of energy crops for the global nitrogen cycle, Ecol. Appl., 20, 101-109, doi:10.1890/08-0608.1, 2010. 
Bowling, L. C. and Lettenmaier, D. P.: Modeling the Effects of Lakes and Wetlands on the Water Balance of Arctic Environments, J. Hydrometeorol., 11, 276-295, 2010.

Bromwich, D. H., Otieno, F. O., Hines, K. M., Manning, K., and Shilo, E.: Comprehensive evaluation of polar weather research and forecasting model performance in the Arctic, J. Geophys. Res.-Atmos., 118, 274-292, 2013.

Buser, C. M., Kuensch, H. R., Luethi, D., Wild, M., and Schaer, C.: Bayesian multi-model projection of climate: bias assumptions and interannual variability, Clim. Dynam., 33, 849-868, 2009.

Chapin, F. S., Matson, P. A., and Mooney, H. A.: Principles of terrestrial ecosystem ecology, Springer-Verlag, New York, USA, 2002

Chen, C., Haerter, J. O., Hagemann, S., and Piani, C.: On the contribution of statistical bias correction to the uncertainty in the projected hydrological cycle, Geophys. Res. Lett., 38, L20403, doi:10.1029/2011GL049318, 2011.

Chen, F. and Dudhia, J.: Coupling an advanced land surfacehydrology model with the Penn State-NCAR MM5 modeling system, Part I: Model implementation and sensitivity, Monthly Weather Rev., 129, 569-585, 2001.

Chen, J., Avise, J., Guenther, A., Wiedinmyer, C., Salathe, E., Jackson, R. B., and Lamb, B.: Future land use and land cover influences on regional biogenic emissions and air quality in the United States, Atmos. Environ., 43, 5771-5780, 2009a.

Chen, J., Avise, J., Lamb, B., Salathé, E., Mass, C., Guenther, A., Wiedinmyer, C., Lamarque, J.-F., O'Neill, S., McKenzie, D., and Larkin, N.: The effects of global changes upon regional ozone pollution in the United States, Atmos. Chem. Phys., 9, 11251141, doi:10.5194/acp-9-1125-2009, 2009b.

Cherkauer, K. and Lettenmaier, D.: Simulation of spatial variability in snow and frozen soil, J. Geophys. Res.-Atmos., 108, D228858, doi:10.1029/2003JD003575, 2003.

Christensen, L., Tague, C. L., and Baron, J. S.: Spatial patterns of simulated transpiration response to climate variability in a snow dominated mountain ecosystem, Hydrol. Proc., 22, 3576-3588, 2008.

Clark, D., Brown, S., Kicklighter, D., Chambers, J., Thomlinson, J., and Ni, J.: Measuring net primary production in forests: Concepts and field methods, Ecol. Appl., 11, 356-370, 2001.

Collins, W. D., Rasch, P. J., Boville, B. A., Hack, J. J., McCaa, J. R., Williamson, D. L., Kiehl, J. T., Briegleb, B., Bitz, C., Lin, S.-J., Zhang, M., and Dai, Y.: Description of the NCAR Community Atmospheric Model (CAM 3.0), National Center for Atmospheric Research, Boulder, CO, 2004.

Dawson, J. P., Racherla, P. N., Lynn, B. H., Adams, P. J., and Pandis, S. N.: Impacts of climate change on regional and urban air quality in the eastern United States: Role of meteorology, J. Geophys. Res.-Atmos., 114, D05308, doi:10.1029/2008JD009849, 2009.

Dee, D. P., Kaellen, E., Simmons, A. J., and Haimberger, L.: Comments on "Reanalyses Suitable for Characterizing Long-Term Trends," Bull. Am. Meteorol. Soc., 92, 65-70, 2011 a.

Dee, D. P., Uppala, S. M., Simmons, A. J., Berrisford, P., Poli, P., Kobayashi, S., Andrae, U., Balmaseda, M. A., Balsamo, G., Bauer, P., Bechtold, P., Beljaars, A. C. M., van de Berg, L., Bidlot, J., Bormann, N., Delsol, C., Dragani, R., Fuentes, M., Geer, A. J., Haimberger, L., Healy, S. B., Hersbach, H., Holm, E. V., Isaksen, L., Kallberg, P., Koehler, M., Matricardi, M., McNally, A. P., Monge-Sanz, B. M., Morcrette, J.-J., Park, B.-K., Peubey,
C., de Rosnay, P., Tavolato, C., Thepaut, J.-N., and Vitart, F.: The ERA-Interim reanalysis: configuration and performance of the data assimilation system, Quart. J. Roy. Meteorol. Soc., 137, 553-597, 2011b.

Duliere, V., Zhang, Y., and Salathe, Jr., E. P.: Extreme Precipitation and Temperature over the U.S. Pacific Northwest: A Comparison between Observations, Reanalysis Data, and Regional Models, JOURNAL OF CLIMATE, 24(7), 1950-1964, doi:10.1175/2010JCLI3224.1, 2011.

Dumont, E., Harrison, J. A., Kroeze, C., Bakker, E. J., and Seitzinger, S. P.: Global distribution and sources of dissolved inorganic nitrogen export to the coastal zone: Results from a spatially explicit, global model, Global Biogeochem. Cy., 19, GB4S02, doi:10.1029/2005GB002488, 2005.

Ehret, U., Zehe, E., Wulfmeyer, V., Warrach-Sagi, K., and Liebert, J.: Should we apply bias correction to global and regional climate model data?, Hydrol. Earth Syst. Sci., 16, 3391-3404, 2012, http://www.hydrol-earth-syst-sci.net/16/3391/2012/.

Elsner, M. M., Cuo, L., Voisin, N., Deems, J. S., Hamlet, A. F., Vano, J. A., Mickelson, K. E. B., Lee, S.-Y., and Lettenmaier, D. P.: Implications of 21 st century climate change for the hydrology of Washington State, Clim. Change, 102, 225-260, 2010.

Folland, C. and Anderson, C.: Estimating changing extremes using empirical ranking methods, J. Climate, 15, 2954-2960, 2002.

Guenther, A. B., Jiang, X., Heald, C. L., Sakulyanontvittaya, T., Duhl, T., Emmons, L. K., and Wang, X.: The Model of Emissions of Gases and Aerosols from Nature version 2.1 (MEGAN2.1): an extended and updated framework for modeling biogenic emissions, Geosci. Model Develop., 5, 1471-1492, 2012.

Haerter, J. O., Hagemann, S., Moseley, C., and Piani, C.: Climate model bias correction and the role of timescales, Hydrol. Earth Syst. Sci., 15, 1065-1079, 2011, http://www.hydrol-earth-syst-sci.net/15/1065/2011/.

Hagemann, S., Chen, C., Haerter, J. O., Heinke, J., Gerten, D., and Piani, C.: Impact of a Statistical Bias Correction on the Projected Hydrological Changes Obtained from Three GCMs and Two Hydrology Models, J. Hydrometeorol., 12, 556-578, 2011.

Hamlet, A. and Lettenmaier, D.: Production of temporally consistent gridded precipitation and temperature fields for the continental United States, J. Hydrometeorol., 6, 330-336, 2005.

Hamlet, A., Mote, P., Clark, M., and Lettenmaier, D.: Effects of temperature and precipitation variability on snowpack trends in the western United States, J. Climate, 18, 4545-4561, 2005.

Hamlet, A. F.: Assessing water resources adaptive capacity to climate change impacts in the Pacific Northwest Region of North America, Hydrol. Earth Syst. Sci., 15, 1427-1443, 2011, http://www.hydrol-earth-syst-sci.net/15/1427/2011/.

Hamlet, A. F., Mote, P. W., Clark, M. P., and Lettenmaier, D. P.: Twentieth-century trends in runoff, evapotranspiration, and soil moisture in the western United States, J. Climate, 20, 1468-1486, 2007.

Hamlet, A. F., Carrasco, P., Deems, J., Elsner, M. M., Kamstra, T., Lee, C., Lee, S.-Y., Mauger, G., Salathe, P., Tohver, I., and Binder, L. W.: Final Project Report for the Columbia Basin Climate CHange Scenarios Project. available at: http://www.hydro. washington.edu/2860/report, 2010.

Hamlet, A. F., Elsner, M. M., Mauger, G., Lee, S.-Y., and Tohver, I.: An overview of the Columbia basin climate change scenarios 
project: approach, methods, and summary of key results, Atmos.Oc., 2012.

Harrison, J. A., Caraco, N., and Seitzinger, S. P.: Global patterns and sources of dissolved organic matter export to the coastal zone: Results from a spatially explicit, global model, Global Biogeochem. Cy., 19, GB4S04, doi:10.1029/2005GB002480, 2005a.

Harrison, J. A., Seitzinger, S. P., Bouwman, A. F., Caraco, N. F., Beusen, A. H. W., and Vorosmarty, C. J.: Dissolved inorganic phosphorus export to the coastal zone: Results from a spatially explicit, global model, Global Biogeochem. Cy., 19, GB4S03, doi:10.1029/2004GB002357, 2005b.

Harrison, J. A., Bouwman, A. F., Mayorga, E., and Seitzinger, S.: Magnitudes and sources of dissolved inorganic phosphorus inputs to surface fresh waters and the coastal zone: A new global model, Global Biogeochem. Cy., 24, GB1003, doi:10.1029/2009GB003590, 2010.

Hoffmann, H. and Rath, T.: Meteorologically consistent bias correction of climate time series for agricultural models, Theoret. Appl. Climatol., 110, 129-141, 2012.

Hong, S. and Pan, H.: Nonlocal boundary layer vertical diffusion in a Medium-Range Forecast Model, Monthly Weather Rev., 124, 2322-2339, 1996.

Hong, S., Dudhia, J., and Chen, S.: A revised approach to ice microphysical processes for the bulk parameterization of clouds and precipitation, Monthly Weather Rev., 132, 103-120, 2004.

Hungerford, R., Nemani, R., Running, S. W., and Coughlan, J. C.: MTCLIM - A mountain microclimate simulation-model, USDA Forest Service Intermountain Research Station Research Paper, 1-52, 1989.

Huntzinger, D. N., Post, W. M., Wei, Y., Michalak, A. M., West, T. O., Jacobson, A. R., Baker, I. T., Chen, J. M., Davis, K. J., Hayes, D. J., Hoffman, F. M., Jain, A. K., Liu, S., McGuire, A. D., Neilson, R. P., Potter, C., Poulter, B., Price, D., Raczka, B. M., Tian, H. Q., Thornton, P., Tomelleri, E., Viovy, N., Xiao, J., Yuan, W., Zeng, N., Zhao, M., and Cook, R.: North American Carbon Program (NACP) regional interim synthesis: Terrestrial biospheric model intercomparison, Ecol. Modell., 232, 144-157, 2012.

Johnson, F. and Sharma, A.: A nesting model for bias correction of variability at multiple time scales in general circulation model precipitation simulations, Water Resour. Res., 48, W01504, doi:10.1029/2011WR010464, 2012.

Kain, J. S. and Fritsch, J. M.: Convective parameterization for mesoscale models: the Kain-Fritsch scheme, in The representation of cumulus convection in numerical models, Am. Meteorol. Soc., 24, 165-170, 1993.

Kimball, J., Running, S., and Nemani, R.: An improved method for estimating surface humidity from daily minimum temperature, Agr. Forest Meteorol., 85, 87-98, 1997.

Lam, Y. F., Fu, J. S., Wu, S., and Mickley, L. J.: Impacts of future climate change and effects of biogenic emissions on surface ozone and particulate matter concentrations in the United States, Atmos. Chem. Phys., 11, 4789-4806, 2011, http://www.atmos-chem-phys.net/11/4789/2011/.

Liang, X., Lettenmaier, D. P., Wood, E. F., and Burges, S. J.: A simple hydrologically based model of land-surface water and energy fluxes for general-circulation models, J. Geophys. Res.-Atmos., 99, 14415-14428, 1994.
Liu, M., Adam, J. C., and Hamlet, A. F.: Spatial-temporal variations of evapotranspiration and runoff/precipitation ratios responding to the changing climate in the Pacific Northwest during 19212006, J. Geophys. Res., 118, 380-394, 2013.

Livezey, R. E. and Chen, W.: Statistical field significance and its determination by monte-carlo techniques, Monthly Weather Rev., 111, 46-59, 1983.

Maraun, D.: Nonstationarities of regional climate model biases in European seasonal mean temperature and precipitation sums, Geophys. Res. Lett., 39, L06706, doi:10.1029/2012GL051210, 2012.

Marsland, S., Haak, H., Jungclaus, J., Latif, M., and Roske, F.: The Max-Planck-Institute global ocean/sea ice model with orthogonal curvilinear coordinates, Ocean Modell., 5, 91-127, 2003.

Maurer, E. P. and Hidalgo, H. G.: Utility of daily vs. monthly largescale climate data: an intercomparison of two statistical downscaling methods, Hydrol. Earth Syst. Sci., 12, 551-563, 2008, http://www.hydrol-earth-syst-sci.net/12/551/2008/.

Maurer, E. P., Wood, A. W., Adam, J. C., Lettenmaier, D. P., and Nijssen, B.: A long-term hydrologically based dataset of land surface fluxes and states for the conterminous United States, J. Climate, 15, 3237-3251, 2002.

Mayorga, E., Seitzinger, S. P., Harrison, J. A., Dumont, E., Beusen, A. H. W., Bouwman, A. F., Fekete, B. M., Kroeze, C., and Van Drecht, G.: Global Nutrient Export from WaterSheds 2 (NEWS 2): Model development and implementation, Environ. Modell. Software, 25, 837-853, 2010.

McCrackin, M. L., Harrison, J. A., and Compton, J. E.: A comparison of NEWS and SPARROW models to understand sources of nitrogen delivered to US coastal areas, Biogeochemistry, 114, 281-297, 2013.

Meentemeyer, R. K. and Moody, A.: Distribution of plant life history types in California chaparral: the role of topographicallydetermined drought severity, J. Vegetat. Sci., 13, 67-78, 2002.

Mote, P.: Trends in snow water equivalent in the Pacific Northwest and their climatic causes, Geophys. Res. Lett., 30, 1601, doi:10.1029/2003GL017258, 2003.

Muerth, M. J., Gauvin St-Denis, B., Ricard, S., Velázquez, J. A., Schmid, J., Minville, M., Caya, D., Chaumont, D., Ludwig, R., and Turcotte, R.: On the need for bias correction in regional climate scenarios to assess climate change impacts on river runoff, Hydrol. Earth Syst. Sci., 17, 1189-1204, doi:10.5194/hess-171189-2013, 2013.

Nakicenovic, N. and Swart, R., (Eds.): IPCC Special Report Emission Scenarios, Cambridge University Press, UK, 2000.

National Research Council: Managing the Columbia River: Instream flows, water withdrawals, and salmon survival, The National Academies Press, Washington, DC, 2004.

Nolte, C. G., Gilliland, A. B., Hogrefe, C., and Mickley, L. J.: Linking global to regional models to assess future climate impacts on surface ozone levels in the United States, J. Geophys. Res.Atmos., 113, D14307, doi:10.1029/2007JD008497, 2008.

Parton, W., Scurlock, J., Ojima, D., Gilmanov, T., Scholes, R., Schimel, D., Kirchner, T., Menaut, J., Seastedt, T., Moya, E., Kamnalrut, A., and Kinyamario, J.: Observations and modeling of biomass and soil organic-matter dynamics for the grassland biome worldwide, Global Biogeochem. Cy., 7, 785-809, 1993.

Peralta, J. M. and Stockle, C. O.: Nitrate from an irrigated crop rotation at the Pasco-Quincy area (Washington, USA) available 
for groundwater contamination: A long-term simulation study, Agriculture, Ecosys. Environ., 88, 23-24, 2002.

Piani, C. and Haerter, J. O.: Two dimensional bias correction of temperature and precipitation copulas in climate models, Geophys. Res. Lett., 39, L20401, doi:10.1029/2012GL053839, 2012.

Piani, C., Weedon, G. P., Best, M., Gomes, S. M., Viterbo, P., Hagemann, S., and Haerter, J. O.: Statistical bias correction of global simulated daily precipitation and temperature for the application of hydrological models, J. Hydrol., 395, 199-215, 2010.

Quintana Segui, P., Ribes, A., Martin, E., Habets, F. and Boe, J.: Comparison of three downscaling methods in simulating the impact of climate change on the hydrology of Mediterranean basins, J. Hydrol., 383, 111-124, 2010.

Roeckner, E., Bengtsson, L., Feichter, J., Lelieveld, J., and Rodhe, H.: Transient climate change simulations with a coupled atmosphere-ocean GCM including the tropospheric sulfur cycle, J. Climate, 12, 3004-3032, 1999.

Roeckner, E., Bauml, G., Bonaventura, L., Brokopf, R., Esch, M., Giorgetta, M., Hagemann, S., Kirchner, I., Kornblueh, L., Manzini, E., Rhodin, A., Schlese, U., Schulzweida, U., and Tompkins, A.: The atmospheric general circulation model ECHAM5, Part I: Model descroption, Max Planck Institute for Meteorology, Hamburg, 2003.

Rosenzweig, C., Jones, J. W., Hatfield, J. L., Ruane, A. C., Boote, K. J., Thorburne, P., Antle, J. M., Nelson, G. C., Porter, C., Janssen, S., Asseng, S., Basso, B., Ewert, F., Wallach, D., Baigorria, G.. and Winter, J. M.: The Agricultural Model Intercomparison and Improvement Project (AgMIP): Protocols and pilot studies, Agricult. Forest Meteorol., 170, 166-182, 2013.

Salathe, P., Hamlet, A. F., Stumbaugh, M., Lee, S.-Y., and Steed, R.: Estimates of 21st Century flood risk in the Pacific Northwest based on regional scale climate model simulations, J. Hydrometeorol., in press, doi:10.1175/JHM-D-13-0137.1, 2013.

Seitzinger, S., Kroeze, C., Bouwman, A., Caraco, N., Dentener, F. and Styles, R.: Global patterns of dissolved inorganic and particulate nitrogen inputs to coastal systems: Recent conditions and future projections, ESTUARIES, 25(4B), 640-655, doi:10.1007/BF02804897, 2002.

Seitzinger, S. P., Harrison, J. A., Dumont, E., Beusen, A. H. W., and Bouwman, A. F.: Sources and delivery of carbon, nitrogen, and phosphorus to the coastal zone: An overview of Global Nutrient Export from Watersheds (NEWS) models and their application, Global Biogeochem. Cy., 19, GB4S01, doi:10.1029/2005GB002606, 2005.

Seitzinger, S. P., Mayorga, E., Bouwman, A. F., Kroeze, C., Beusen, A. H. W., Billen, G., Van Drecht, G., Dumont, E., Fekete, B. M., Garnier, J. and Harrison, J. A.: Global river nutrient export: A scenario analysis of past and future trends, Global Biogeochem. Cy., 24, GB0A08, doi:10.1029/2009GB003587, 2010.

Shepard, D. S.: Computer mapping: the SYMAP interpolation algorithm, in Spatial Statistics and Models, 1984.

Skamarock, W. C., Klemp, J. B., Dudhia, J., Gill, D. O., Barker, D. M., Duda, M., Huang, X. Y., Wang, W., and Powers, J. G.: A Description of the Advanced Research WRF Version 3, Mesoscale and Microscale Meteorology Division, National Center for Atmospheric Research, Boulder, Colorado, USA, 2008.

Stockle, C., Martin, S., and Campbell, G.: CropSyst, a cropping systems simulation-model - water nitrogen budgets and crop yield, Agr. Systems, 46, 335-359, 1994.
Stockle, C. O., Donatelli, M., and Nelson, R.: CropSyst, a cropping systems simulation model, European J. Agronomy, 18, 289-307, 2003.

Tague, C. and Grant, G. E.: Groundwater dynamics mediate low-flow response to global warming in snowdominated alpine regions, Water Resour. Res., 45, W07421, doi:10.1029/2008WR007179, 2009.

Tague, C., Farrell, M., Grant, G., Lewis, S., and Rey, S.: Hydrogeologic controls on summer stream temperatures in the McKenzie River basin, Oregon, Hydrol. Proc., 21, 3288-3300, doi:10.1002/hyp.6538, 2007.

Tague, C., Valentine, S., and Kotchen, M.: Effect of geomorphic channel restoration on streamflow and groundwater in a snowmelt-dominated watershed, Water Resour. Res., 44, W10415, doi:10.1029/2007WR006418, 2008.

Tague, C., Heyn, K. and Christensen, L.: Topographic controls on spatial patterns of conifer transpiration and net primary productivity under climate warming in mountain ecosystems, Ecohydrology, 2, 541-554, 2009.

Tague, C. L. and Band, L. E.: RHESSys: Regional Hydro-Ecologic Simulation System-An Object-Oriented Approach to Spatially Distributed Modeling of Carbon, Water, and Nutrient Cycling, Earth Interactions, 8, 1-42, 2004.

Tague, C. L., Choate, J. S., and Grant, G.: Parameterizing subsurface drainage with geology to improve modeling streamflow responses to climate in data limited environments, Hydrol. Earth Syst. Sci., 17, 341-354, 2013, http://www.hydrol-earth-syst-sci.net/17/341/2013/.

Taylor, K. E., Stouffer, R. J., and Meehl, G. A.: an overview of cmip5 and the experiment design, bulletin of the american meteorological society, 93, 485-498, 2012.

Teutschbein, C. and Seibert, J.: Bias correction of regional climate model simulations for hydrological climate-change impact studies: Review and evaluation of different methods, J. Hydrol., 456, 12-29, 2012.

Themessl, M. J., Gobiet, A., and Leuprecht, A.: Empiricalstatistical downscaling and error correction of daily precipitation from regional climate models, Internat. J. Climatol., 31, 15301544, 2011.

Thieu, V., Mayorga, E., Billen, G., and Garnier, J.: Subregional and downscaled global scenarios of nutrient transfer in river basins: Seine-Somme-Scheldt case study, Global Biogeochem. Cy., 24, GB0A10, doi:10.1029/2009GB003561, 2010.

Thorne, P. W. and Vose, R. S.: Reanalyses Suitable for Characterizing Long-Term Trends, Bull. Amer. Meteor. Soc., 91, 353-361, 2010 .

Thornton, P. and Running, S.: An improved algorithm for estimating incident daily solar radiation from measurements of temperature, humidity, and precipitation, Agricult. Forest Meteorol., 93, 211228, 1999.

Thornton, P., Hasenauer, H., and White, M.: Simultaneous estimation of daily solar radiation and humidity from observed temperature and precipitation: an application over complex terrain in Austria, Agricult. Forest Meteorol., 104, 255-271, 2000.

Thrasher, B., Park, M., Xiong, J., Wang, W., and Nemani, R.: Downscaled climate projections suitable for resource management, Eos, 94, 321-323, 2013.

USDA National Agricultural Statistics Service: 2008 Farm and Ranch Irrigation Survey, available at: 
http://www.agcensus.usda.gov/Publications/2007/Online_ Highlights/Farm_and_Ranch_Irrigation_Survey/fris08.pdf (last access: 3 April 2013), 2008.

USDA National Agricultural Statistics Service Cropland Data Layer: Published crop-specific data layer, available at: http: //nassgeodata.gmu.edu/CropScape/ (last access: 30 December 2012), 2011.

Van Drecht, G., Bouwman, A. F., Harrison, J., and Knoop, J. M.: Global nitrogen and phosphate in urban wastewater for the period 1970 to 2050, Global Biogeochem. Cy., 23, GB0A03, doi:10.1029/2009GB003458, 2009.

Vannitsem, S.: Bias correction and post-processing under climate change, Nonlinear Proc. Geophys., 18, 911-924, 2011.

Von Storch, H.: A remark on Chervin-Schneider's algorithm to test significance of climate experiments with GCM's, J. Atmos. Sciences, 39, 187-189, 1982.

White, J. D. and Running, S. W.: Testing scale-dependent assumptions in regional ecosystem simulations, J. Vegetat. Sci., 5, 687702, 1994.

Wilks, D. S.: On "field significance" and the false discovery rate, J. Appl. Meteorol. Climatol., 45, 1181-1189, 2006.

Wood, A., Maurer, E., Kumar, A., and Lettenmaier, D.: Long-range experimental hydrologic forecasting for the eastern United States, J. Geophys. Res.-Atmos., 107, D204429, doi:10.1029/2001JD000659, 2002.
Wood, A., Leung, L., Sridhar, V., and Lettenmaier, D.: Hydrologic implications of dynamical and statistical approaches to downscaling climate model outputs, Clim.c Change, 62, 189-216, 2004.

Wood, E. F., Roundy, J. K., Troy, T. J., van Beek, L. P. H., Bierkens, M. F. P., Blyth, E., de Roo, A., Doell, P., Ek, M., Famiglietti, J., Gochis, D., van de Giesen, N., Houser, P., Jaffe, P. R., Kollet, S., Lehner, B., Lettenmaier, D. P., Peters-Lidard, C., Sivapalan, M., Sheffield, J., Wade, A., and Whitehead, P.: Hyperresolution global land surface modeling: Meeting a grand challenge for monitoring Earth's terrestrial water, Water Resour. Res., 47, W05301, doi:10.1029/2010WR010090, 2011.

Yorgey, G. G., Rajagopalan, K., Chinnayakanahalli, K., Brady, M. P., Barber, M. E., Nelson, R., Stockle, C. O., Kruger, C. E., Dinesh, S., Malek, K., Yoder, J., and Adam, J. C.: Columbia River Basin Long-Term Water Supply and Demand Forecast, available at: http://www.ecy.wa.gov/biblio/1112011.html (last access: 3 April 2013), 2011.

Zhang, Y., Duliere, V., Mote, P. W., and Salathe, Jr., E. P.: Evaluation of WRF and HadRM Mesoscale Climate Simulations over the US Pacific Northwest, J. Climate, 22, 5511-5526, 2009.

Zierl, B. and Bugmann, H.: Global change impacts on hydrological processes in Alpine catchments, Water Resour. Res., 41, W02028, doi:10.1029/2004WR003447, 2005. 